$31(1) \mid 2002$

Varia

\title{
El simbolismo en torno al agua en la comunidad de Huaros-Canta
}

Le Symbolisme lié à l'eau dans la communauté de Huaros-Canta

Water-Related Symbolism in the Community of Huaros, Canta province

\section{Carlos Farfán Lobaton}

\section{OpenEdition}

Journals

Edición electrónica

URL: http://journals.openedition.org/bifea/6967

DOI: $10.4000 /$ bifea. 6967

ISSN: 2076-5827

Editor

Institut Français d'Études Andines

Edición impresa

Fecha de publicación: 1 abril 2002

Paginación: 115-142

ISSN: 0303-7495

\section{Referencia electrónica}

Carlos Farfán Lobaton, « El simbolismo en torno al agua en la comunidad de Huaros-Canta », Bulletin de l'Institut français d'études andines [En línea], 31 (1) | 2002, Publicado el 08 abril 2002, consultado el 08 diciembre 2020. URL : http://journals.openedition.org/bifea/6967 ; DOI : https://doi.org/10.4000/ bifea.6967

Este documento fue generado automáticamente el 8 diciembre 2020.

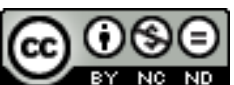

Les contenus du Bulletin de l'Institut français d'études andines sont mis à disposition selon les termes de la licence Creative Commons Attribution - Pas d'Utilisation Commerciale - Pas de Modification 4.0 International. 


\title{
El simbolismo en torno al agua en la comunidad de Huaros-Canta
}

\author{
Le Symbolisme lié à l'eau dans la communauté de Huaros-Canta \\ Water-Related Symbolism in the Community of Huaros, Canta province
}

\author{
Carlos Farfán Lobaton
}

Este trabajo fue posible gracias al apoyo desinteresado de la Comunidad Campesina de Santiago de Huaros con quienes aprendí a entender la cultura andina, especialmente al Sr. Emilio Torres Mosquito quien me facilitó su casa en Huaros durante todas las fechas de mi estadía, al Dr. Edwin Santos Hurtado con quien recorrimos en busca de los comuneros más ancianos, tanto en Lima como en Huaros, al Sr. Alfonso Astudillo de 94 años, Eduardo León Soto, Benigno Hacha Mosquito, Agustín Reyes Arsenio, José Masgo Astudillo y a todos aquellos que tuvieron paciencia con mis preguntas e inquietudes.

\section{El Área de estudio}

1 Huaros es distrito de la Provincia de Canta (Fig.1); se halla a 3587 m.s.n.m. en la margen derecha del río Chillón, sobre una gran terraza morrénica y a $300 \mathrm{~m}$ de altura encima del lecho del río (Fig. 2). Posee dos sitios arqueológicos denominados Huishco y Aynas. Huishco se ubica a 4050 m.s.n.m., sobre la cumbre de una formación rocosa alargada, al noroeste del poblado de Huaros mientras que Aynas está situado al noreste del mismo poblado, sobre un gran promontorio, al pie del cerro Chullahuani a 3650 m.s.n.m. Estos dos sitios arqueológicos corresponden al Período Intermedio Tardío (siglo XI d.C.), pero también incluyen rasgos arquitectónicos de la ocupación Inca. 
Fig. 1 - Mapa de ubicación

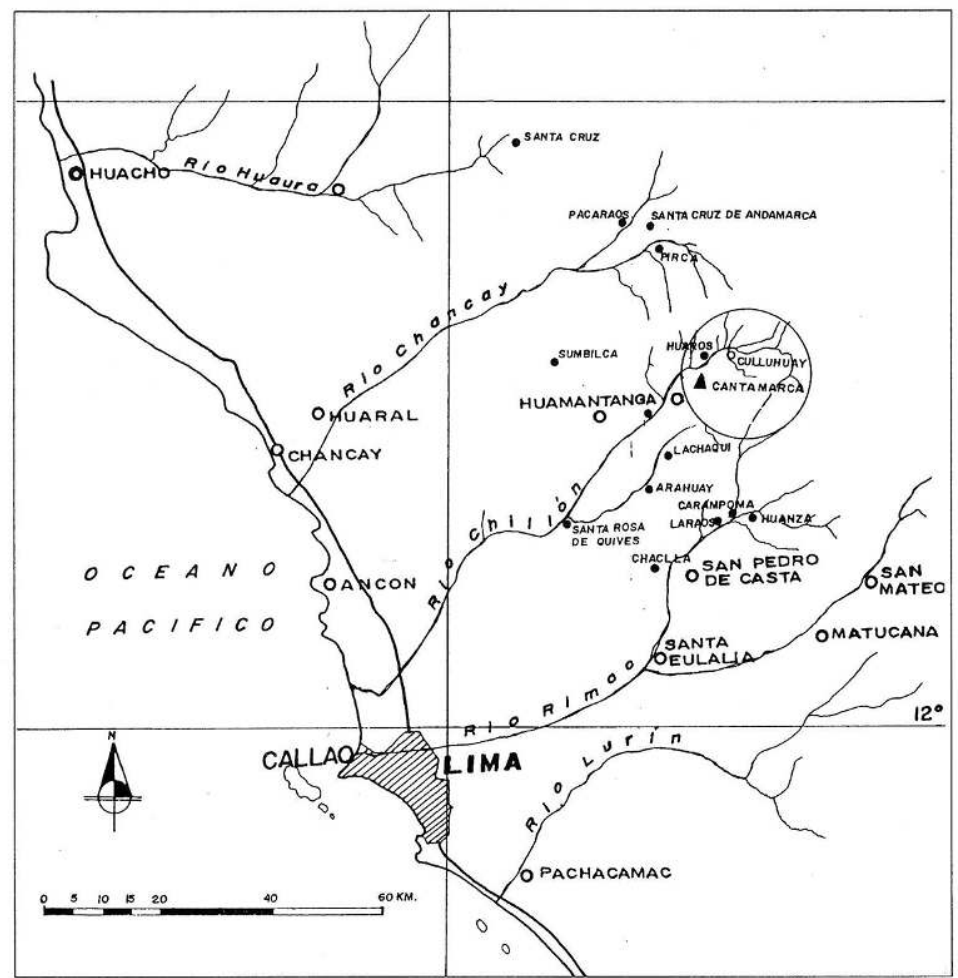

Fig. 2 - Vista panorámica del poblado de Huaros con sus terrazas de cultivo

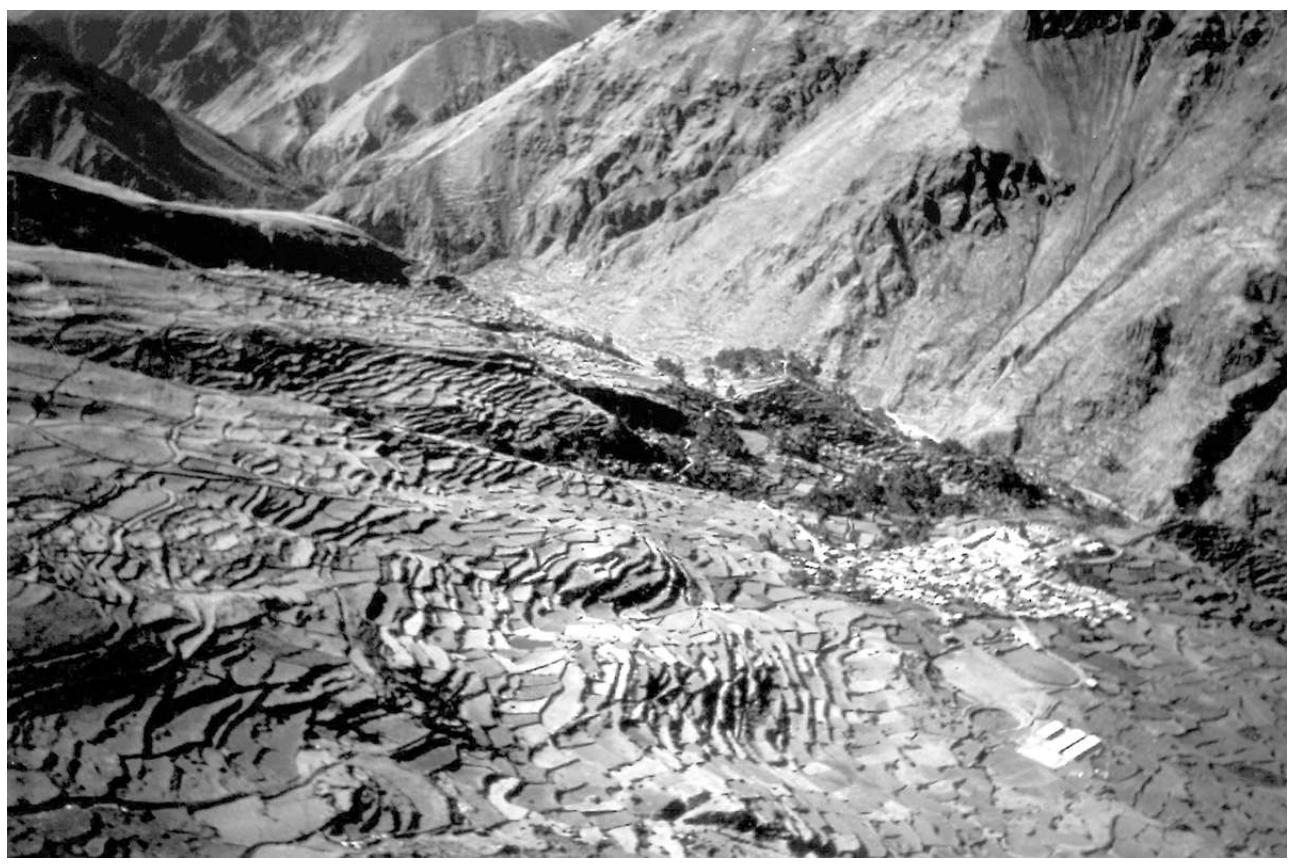

2 El distrito de Huaros posee tres anexos: Culluhuay, Huacos y Acochaca ubicados en distintos pisos ecológicos (Fig. 3), en la margen derecha del río Chillón. De las escasas tierras de cultivo que poseen, el 95\% esta conformado por un conjunto de terrazas construidas en época prehispánica, pero ahora están muy deterioradas debido a la constante erosión. Aun así esta población depende de la agricultura donde se produce 
básicamente papas (Solanum Tuberosum), oca (Oxalis tuberosa), olluco (Ullucos tuberosus) y haba (Vicia fava), con permanente problema de escasez de agua; complementan esta actividad con la ganadería, la crianza de vacunos, ovinos y camelidos; en la actualidad poseen una piscigranja comunal.

Fig. 3 - Mapa de flujo del agua en la comunidad de Huaros-Canta

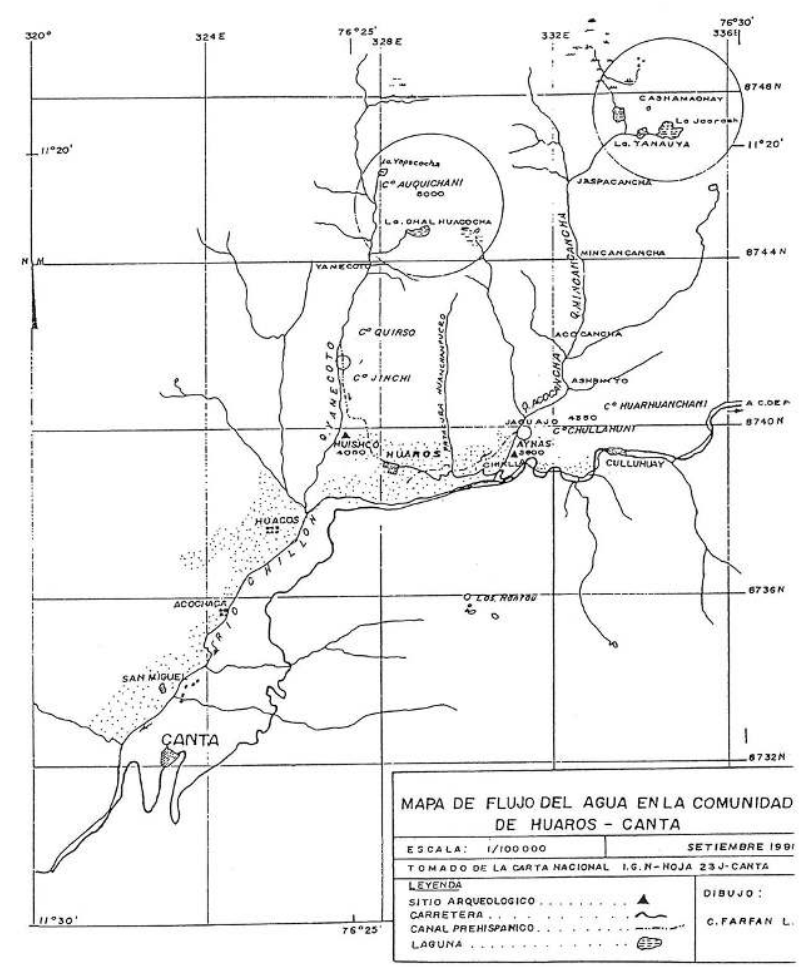

\section{Huishco y Aynas Ñaupallactas de Huaros (Época prehispánica)}

Huishco y Aynas son los pueblos viejos de Huaros; se remontan a la época pre-inca y coexistieron cronológicamente funcionando como dos entidades complementarias en el manejo de su economía y en el control territorial de la margen derecha del río Chillón. Aynas tenía dominios hacia las zonas de la cordillera de La Viuda con grandes áreas de pastizales (margen derecha de Culluhuay) y una parte de los terrenos para cultivo en tierras más bajas. De igual manera, Huishco controlaba parte de las punas (cuencas del Llamecoto y Auquichani) con ganadería y tierras de cultivo en terrazas controladas por riego en los terrenos del actual Huaros.

Durante el Período Intermedio Tardío (siglos XI al XV), Aynas parece haber adquirido un rol muy importante de control y nexo con pueblos de la margen izquierda (Cushpa, Carcas, Cantamarca), mientras que Huishco mantenía relación con los poblados de zonas mas bajas de Huacosmarca, Pumacoto, Auquimarca y Tauripuncu de la margen derecha.

Entre Huishco y Aynas, se puede notar diferencias en el tamaño del asentamiento, siendo Aynas el de mayor extensión (Fig. 4). En lo que respecta al patrón arquitectónico en Huishco, es posible encontrar pilastras troncocónicas como elementos de soporte, 
mientras que en Aynas es usual la columna central del tipo Cantamarca. Esto explicaría, en cierto modo, una relación cultural mas cercana con la margen izquierda (Farfán, 1995). De otro lado, Aynas se caracteriza por ser un asentamiento concentrado con una organización racional del espacio, diferente al de Huishco que tiende a ser dispersa con áreas de influencia externa provenientes posiblemente de los Atavillos Altos. Este sitio ocupa una cresta rocosa sobre la cual edificaron y acondicionaron sus construcciones (Fig. 5). Básicamente son formas arquitectónicas que adoptan bases ovaladas (Fig. 6) y rectangulares con esquinas curvas (Fig. 7). Estos últimos edificios poseen aleros y cornisas de mayor longitud semejantes a los de Chiprac y Rupac en la cuenca del Chancay (Farfán, 1995); pero en ambos casos los incas impusieron modificación y/o remodelación de los espacios arquitectónicos, así como de los sistemas constructivos propios y adecuaron a nuevos usos los ya existentes.

Fig. 4 - Plano general de Aynas, Huaros-Canta

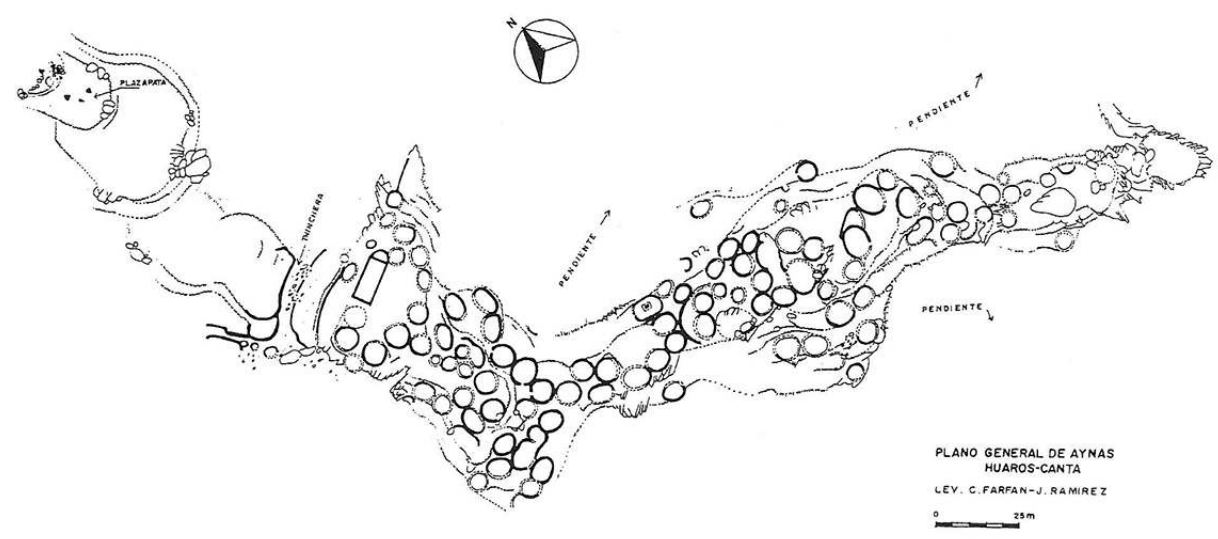

Fig. 5 - Plano preliminar de Huishco Huaros

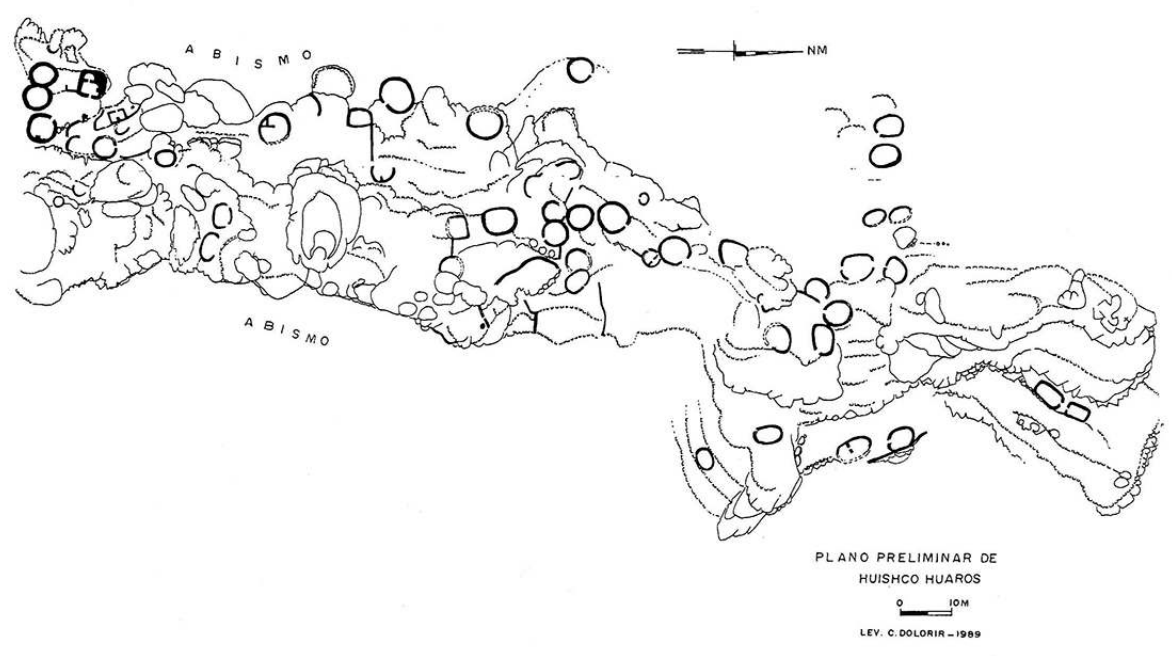


Fig. 6 - Edificio típico de Huishco con planta ovalada

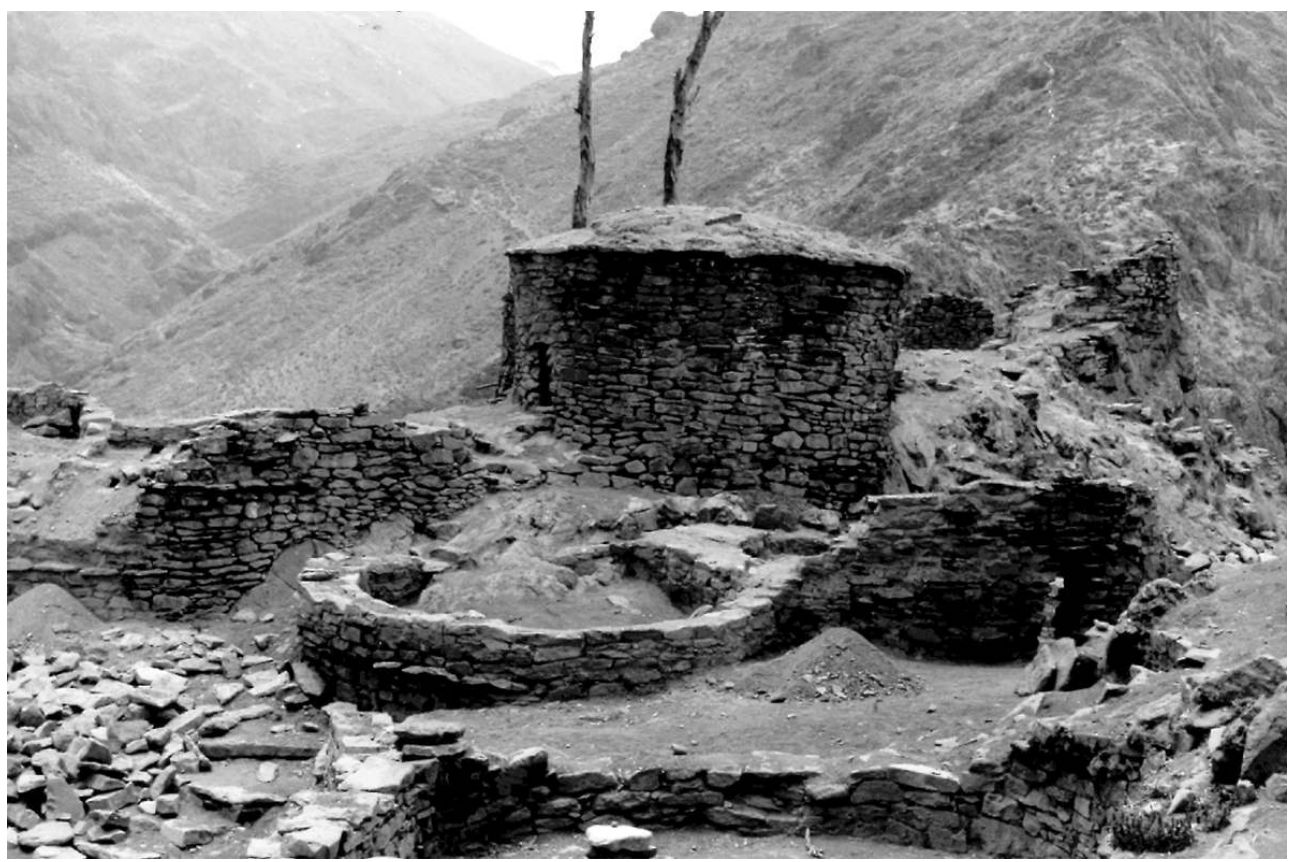

Fig. 7 - Sector con recintos ovalados y cuadrangulares en Huishco similares a Rupac

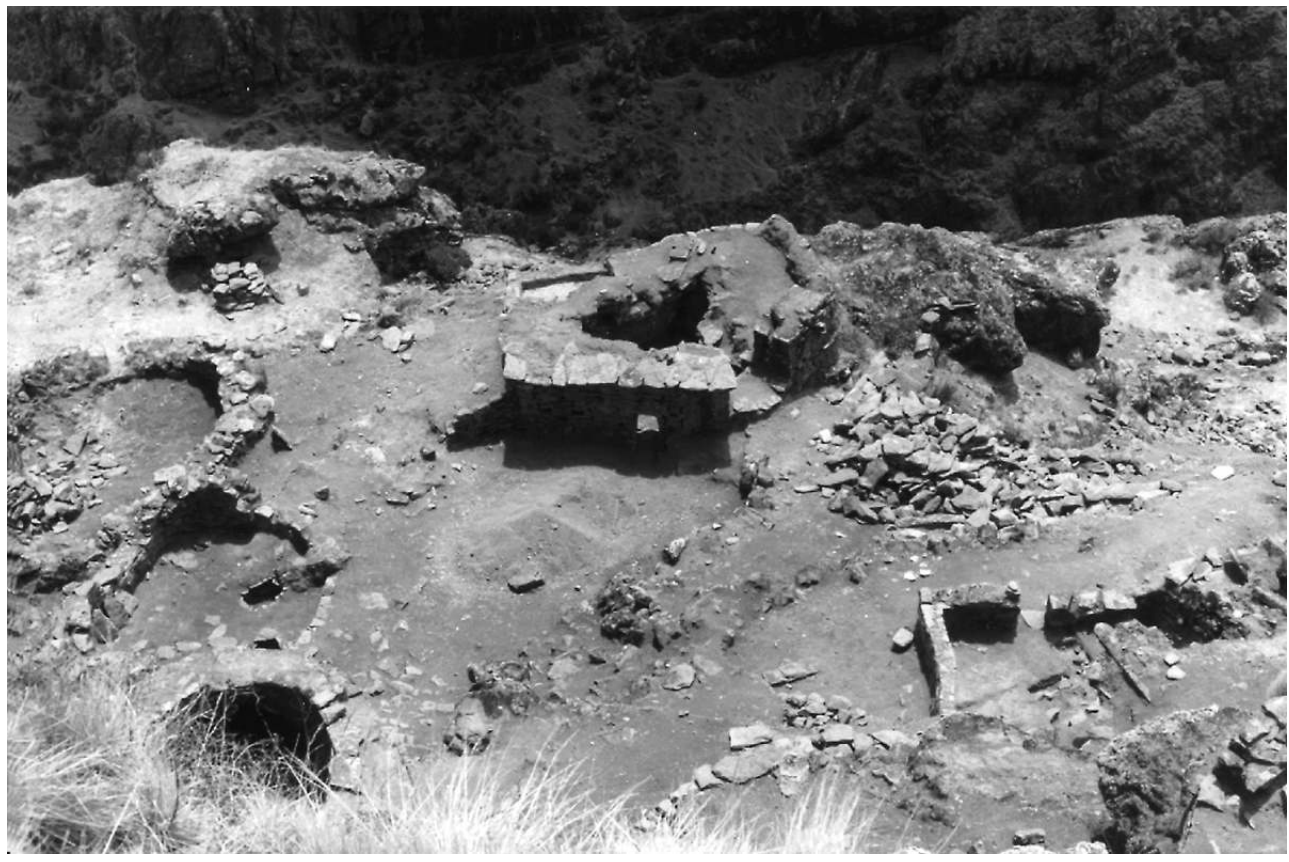

3 A la llegada de los españoles se implantaron las reducciones aplicadas por Francisco de Toledo (1570). Con este acto se reubicó a las antiguas poblaciones establecidas generalmente en las cumbres altas, hacia zonas más bajas, lo que originó un cambio súbito de lugar de los pueblos prehispánicos, trastocando de este modo las costumbres y tradiciones ligadas a sus antiguos pueblos, huacas, pacarinas; a sus tumbas y mallquis. De manera que los pobladores de Aynas y Huishco fueron arrancados de sus espacios originarios y reubicados en lo que hoy es el poblado de Huaros. Pero aún así, no llegó a afectar sus tradiciones, costumbres y pensamientos, razón por la cual "mantuvieron sus 
mismas organizaciones étnicas, conformando los barrios de Huaroslao para los provenientes de Huishco y Huanarpun para los provenientes de Aynas“ (Farfán, 1993). De este modo, en la actualidad aún conservan su identidad original, de la cual quedan pocas referencias. Por esta razón, en el pensamiento del huarosino, persiste la idea de su origen según el barrio donde se ubiquen. Hay testimonios que precisan los límites hasta dónde se extendieron los territorios de los aynas y los huishco. Don Agustín Reyes Arsenio, huarosino de 71 años, nos dijo que cuando él era joven escuchaba decir a sus padres que la divisoria de las tierras de Aynas y Huishco era la quebrada de Patacura o Huanchanpucro, que es un límite natural (Fig. 3). Las tierras de Aynas se llamaban Hatunpucro-Huanarpun y las de Huishco, Hatunpucro-Huaros. Actualmente esta denominación se viene perdiendo debido a factores externos y a las alianzas matrimoniales que han generado vínculos de parentesco, dando lugar al acceso a tierras de uno y otro barrio.

Como podemos notar, es muy fácil diferenciar la denominación espacial de los linderos territoriales con nombres que aún se conservan cuando se refieren al poblado (Huaroslao o Huanarpun) o cuando se refieren al territorio o jurisdicción (Hatun Pucru Huaros o Hatun Pucru Huanarpun). Esta diferenciación puede estar indicándonos la connotación de origen y dominios que se mantuvieron incluso después de la ocupación inca y las reducciones hechas por los españoles que derivó en la bipartición del espacio en el actual Huaros. Sin embargo, debemos tomar en cuenta también que podría estar formando parte de una división complementaria Anan y Urin en base a un criterio hidráulico (Valderrama \& Escalante, 1988: 216).

\section{Consideraciones Previas}

5 Durante nuestras investigaciones arqueológicas y etnográficas en la cuenca alta del Chillón hemos encontrado abundante información que explica la continuidad cultural basada en creencias, tradiciones orales y tecnología ancestral relacionada con el riego y control del agua bajo esquemas simbólicos que perduran hasta la actualidad, pero que inexorablemente están condenados a desaparecer conforme avanzan la modernidad y la tecnología.

6 Nuestro propósito, es intentar explicar algunos elementos simbólicos en torno a los mitos y creencias mágico-religiosas en relación con el agua, las mismas que están vinculadas a la circulación del agua y el origen del pueblo de Huaros.

7 En primer término nos referiremos a un concepto muy importante dentro de la cosmología andina en relación con el agua y los mitos de origen. Uno de ellos, se refiere a la idea de que los lagos son el origen de otras fuentes y que sus aguas provienen del mar (Sherbondy,1982: 3). La relación lago-mar, en el área andina, tiene una connotación de dualidad dentro de términos espaciales cuando se refiere a las fuentes hidrológicas de la costa y sierra. Consecuentemente se denominan "las aguas de arriba" y "las aguas de abajo"; pero lo fundamental dentro de esta dicotomía es la relación madre-hija, siendo el mar la Madre (mamacocha) y los lagos y lagunas las hijas (cochas), lo que explicaría implícitamente que el agua de los lagos proviene del mar. Polo de Ondegardo nos señala lo siguiente:

"Item, sacrificavan u ofrecían conchas de la mar que llamaban mollo. Y ofrecían a las fuentes y manantiales, diziendo que las cochas eran hijas de la mar, madre de todas las aguas" (Polo, 1917[1571]). 
8 A este respecto hemos recogido datos de campo en las comunidades campesinas del alto Chillón. El comunero Don Agustín Reyes Arsenio, nos dijo:

"Había un señor que era huishito (viejito), yo recuerdo todavía, le mandaban a la laguna de Yanauya bien enflorado, bien despachado, en la madrugada a hondear ${ }^{1}$ la laguna, y llegaba como a las 2 ó 3 de la tarde, yo estaba chico, y decían jya llegó taita Joshe!, ya esta llegando la lluvia. Entre el sol y la lluvia sabía estar llegando."

9 Otro informante del mismo poblado, Don Eduardo León Soto de 78 años, al referirse al mismo problema, nos señala que el agua que se traía del mar en cántaros, se derramaba en parte sobre la torre de la iglesia mediante rituales de invocación a la fe católica y lo que quedaba se enviaba para la laguna de Turuman cerca de la cordillera de la Viuda donde dicen que:

“... de esta laguna salen las nubes. Esta agua es llevada por una persona algo inválida, que no tenga uno de los brazos o este tullido para hondear la laguna hacia las nubes dando gritos ¡Que llueva señor!.. ¡Que llueva señor! En esta ceremonia acompaña también, un mellizo con un padrino quien es el que le baña en la laguna. Este niño tiene que pedir a gritos que caiga la lluvia mirando al cielo."

10 Esta última versión es casi similar a la anterior aunque aparecen tres personajes en este ritual: el tullido o inválido, el mellizo y el padrino. Además, se nombran lagunas distintas en ambas versiones (Yanauya y Turuman). Sin embargo, otro de nuestros informantes, que ha radicado en forma permanente en Huaros, el Señor José Masgo Astudillo de 78 años, nos dijo que este personaje que iba a la laguna de Yanauya llevando agua de mar para realizar los ritos de propiciación, era un personaje con el labio leporino del que decían todos que era hijo del rayo, por lo que le tenían mucha estimación y respeto. Este relato difiere sustancialmente de los anteriores. No sabemos cuáles son los factores que originaron estas versiones, quizá sean las diferencias de origen en relación con los que se consideran originarios de Aynas o Huishco. Con respecto a este relato tenemos la versión de Joseph Arriaga quien nos dice:

"Quando nacen dos de vn parto, que como dizimos arriva llaman Chuchos, o Curi, y en el Cuzco Taqui Huahua, lo tienen por cosa sacrílega, y abominable, y aunque dizen, que el vno es hijo del rayo" (Arriaga, 1920: 56).

11 Otra cita de Cristobal de Albornoz señala en los mismos términos:

“También llaman Illapa a los niños geminos que salen dos o mas de un vientre y los suelen sacrificar a los rayos y truenos diziendo son sus hijos" (Duviols, 1967: I, 19).

12 Estas citas, tanto de Arriaga como de Albornoz, tienen relación con los dos últimos relatos, sobre todo cuando se refieren a que el mellizo es hijo del rayo, aunque el relato del señor Soto nos plantea ciertas dudas, puesto que se podría estar mezclando relatos que se refieren más bien al poblado de Culluhuay ${ }^{2}$ en donde ha radicado más tiempo, por lo que habría que tomar en cuenta este aspecto. Sin embargo, algunos huarosinos nos informaron que estos ritos también se hacían en la laguna de Chuchun ${ }^{3}$ donde el mellizo lanza piedras con la honda hacia la huaca que reside en dicha laguna, huaca relacionada, según el mito, al poblado de Culluhuay.

13 Arriaga, repetidas veces, menciona que los mellizos son considerados hijos del rayo y cuando mueren son enterrados en una vasija y venerados (Arriaga, 1920: 30), de manera que se establece una relación rayo-mellizo. El rayo es parte de las deidades dadoras de lluvia y fertilidad (Mariscotti, 1972: 207) que vendría a ser también padre de los mellizos y de aquellos que nacen con el labio leporino. Mientras que los cerros están vinculados con los fenómenos meteorológicos (Martinez, 1983: 87) como el rayo, el trueno, las lluvias, illapa o el arcoiris que permiten la llegada de las lluvias; aunque, 
estos mismos fenómenos pueden convertirse en destructores, tales como las lluvias torrenciales y granizo que generan los llamados huaycos o llocllas que pueden dañar las poblaciones y tierras de cultivo.

14 En Lachaqui ${ }^{4}$ persiste otro ritual sobre la "la búsqueda del agua". Cada 4 de enero, las autoridades del agua (Inspector y Alguaciles), se reúnen secretamente en la noche, en una casa abandonada alejada del pueblo y eligen quienes irán a buscar el agua de los manantiales que sólo ellos conocen. Estas aguas se consideran provenientes del mar, por lo que deben ser recogidas de los manantiales indicados y no de otros. Con estas aguas recaudadas en distintos puquios o manantiales, se ejecuta un ritual en la cumbre de la huaca (Cerro Cullpe, antiguo ñaupallacta de Lachaqui): aquí se entierran las botellas paradas y orientadas en todas las direcciones. Este ritual se hace con el propósito de propiciar la llegada del agua y evitar la sequía en este pueblo. Lo importante en este relato es que no todos los puquios provienen del mar, es más, nuestro informante nos dijo que estas aguas tenían poderes y para cogerlos había que ser elegido y aceptado por Parianhuasi, una huaca que radica en el cerro Pallpay al cual se rinde culto en cada limpia acequia porque dicen que él es el "señor de las aguas".

Como hemos podido apreciar, este primer concepto referido a las aguas tiene una articulación basada en la circulación del agua: las aguas que discurren por la superfice (ríos y canales), las aguas que circulan por el subsuelo (puquios) y las aguas de mar. El agua de mar tiene una significación muy importante en los rituales de propiciación y fertilidad en el mundo andino. En la comunidad de Yanque, Arequipa se afirma los siguiente:

"Dicen cuando echan el agua del mar a los ojos de los manantes, viene la lluvia, llama la lluvia, es para que no se seque los ojos" versión de C. Vilcazan (Valderrama \& Escalante, 1988: 104).

En la misma comunidad el Yana afirma:

"La vena debe siempre venir del mar; cómo podría salir durante todo el tiempo agua de un cerro seco. Si orinase, cómo podría orinar sin terminar nunca. El agua debe ser vena que viene desde el mar" (Valderrama y Escalante, 1988: 102).

17 Por esta razón, el agua de mar, al igual que las conchas marinas, desempeñaba un papel importante en el culto a los cerros para la concesión de lluvias en toda la región de los Andes (Martinez, 1976: 301). De este modo, tiene una explicación coherente el significado de las aguas de mar, lagunas, nevados y manantiales en el pensamiento del hombre andino.

Consideramos necsario mencionar otro conecpto sobre la circulación del agua, basado en otro mito de origen muy arraigado en el mundo andino y relacionado con lo siguiente:

"el mundo se pobló cuando Viracocha mandó a los antepasados que caminasen por debajo de la tierra, desde el lago Titicaca, hasta emerger por las lagunas, manantiales, ríos, cerros o raíces de árboles donde fundaron sus ayllus. Los muertos que, por consiguiente, se han convertido en antepasados, retornan a las fuentes de su existencia, que también son fuentes de agua. De esta manera las relaciones hidrológicas reales y posibles se extienden hasta incluir relaciones simbólicas para expresar conceptos de orígenes y etnicidad." (Sherbondy, 1982)

Esta síntesis encierra la relación antepasado-origen-fundación de los pueblos. La podemos complementar con la relación montaña-agua-fertilidad (Reinhard, 1987), donde las montañas son divinidades de propiciación de las lluvias y lugares donde reside el Wamani o dioses que controlan la circulación del agua a través de los canales. 
Sabemos también que las montañas elevadas pueden ser los nevados que garantizan la abundancia o escasez de agua. En Yanque el nevado Mismi es masculino mientras que el agua de mar es femenino al igual que el agua del manantial Humahala. En este caso, podemos tener una tripartición simbólica del agua: manantial, nevado y mar que forman una unidad del mismo elemento, pero que funcionan dentro una circulación racional asociando la mamapacha (cerro, montaña) y la mamacocha (mar), a través de los circuitos subterráneos (puquios o manantiales) y sobre la superficie (lagunas, ríos y canales).

Las montañas o cerros siempre han formado parte de la vida cotidiana de los poblados del mundo andino como protectores y guardianes, es decir, se consideran la morada de los dioses. En el caso de Wallallo se dice que este residía temporalmente en algunos de los grandes templos construidos en los más elevados peñones (Tello, 1923: 510). La gran mayoría de los nevados, volcanes y cerros muy altos contienen restos arqueológicos asociados a enterramientos o instalaciones para rituales propiciatorios al que se les ha denominado "montañas sagradas" (Reinhard, 1983; Constanza, 1999: 27). Sin embargo, durante el desarrollo de la fiesta de limpia acequia se visualizan la mayoría de los ritos propiciatorios donde estrechan vínculos que unen a los comuneros con sus divinidades y antepasados (mallkos) identificados por lugares sagrados, tales como plazas, cuevas, cerros, piedras, acequias, etc. Arriaga también menciona:

"A cerros altos, y montes y lagunas piedras muy grandes también adoran, y mochan, y les llaman con nombres particulares" (Arriaga, 1920).

21 Por esta razón, cada pueblo del mundo andino posee uno o dos cerros tutelares con sus respectivas huacas. En Huaros sobresalen los cerros Jinchi, Auquichani y Chullahuani (Fig. 3). Tanto en Jinchi como en Chullahuani existen una cruz que se venera en cada limpia acequia o fiesta del agua. La cruz de Jinchi está relacionada con el canal de Millpo y una huaca; la de Chullahuani, con el canal de Jaguajo y dos huacas, de modo que en estos dos espacios, el cristianismo con la cruz y lo andino con la huaca, se sincretizan en un solo ritual. Auquichani es un nevado que da origen a las lagunas de Chalhuacocha y Yapacocha de donde nace el riachuelo de Yamecoto que abastecía a la antigua población de Huishco en época prehispánica y ahora al pueblo de Huaros a través del canal de Millpo. Chullahuani es un cerro de forma cónica que aparenta ser un volcán al pie del cual se halla el antiguo asentamiento de Aynas, hoy ruinas de Aynas. Junto a ellas discurre el riachuelo de Acocancha que abastecía a la antigua población de Aynas y en la actualidad irriga las tierras bajas de Huaros a través del canal prehispánico de Jaguajo. Este cerro parece tener una pareja, puesto que más al noreste y en posición contigua, se halla el cerro Huarhuanchani, de manera que junto con Chullahuani formarían una trilogía de auquis relacionados con Huaros: AuquichaniChullahuani-Huarhuanchani que pertenecerían a un mismo contexto de montañas sagradas. De este modo, está presente la circulación mítica del agua en la cosmovisión del huarosino que se sintetiza bajo cuatro elementos simbólicos, presentes en sus rituales:

22 - Los cerros y nevados tutelares donde residen los mallquis o ancestros;

23 - las huacas simbolizadas en piedras o huancas que son dueñas del agua y quizá, los ancestros litificados ${ }^{5}$, que controlan la fertilidad de la tierra y los animales (Figs. 8, 9, 10 y 11);

24 - las lagunas, de donde nacen los ríos, consecuentemente los canales; 
- los manantiales que brotan de las entrañas de los cerros y provienen del mar.

Fig. 8 - La Huaca denominada "el viejo" ubicada cerca a la loma del canal Jaguajo

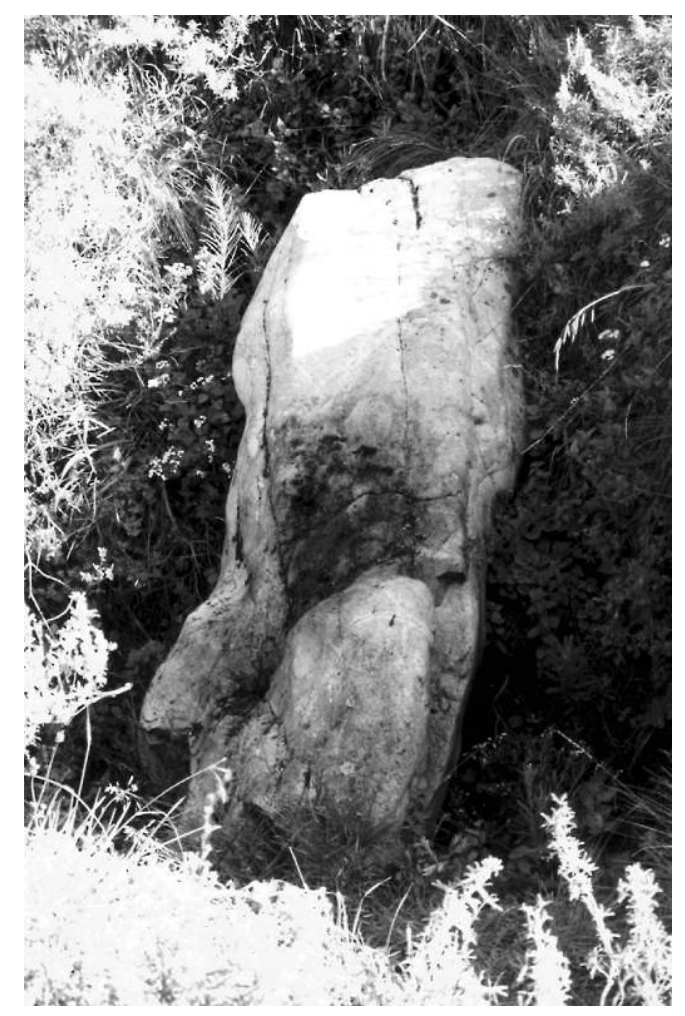

Fig. 9 - Mallcos o conopas halladas en las excavaciones arqueológicas en Huishco

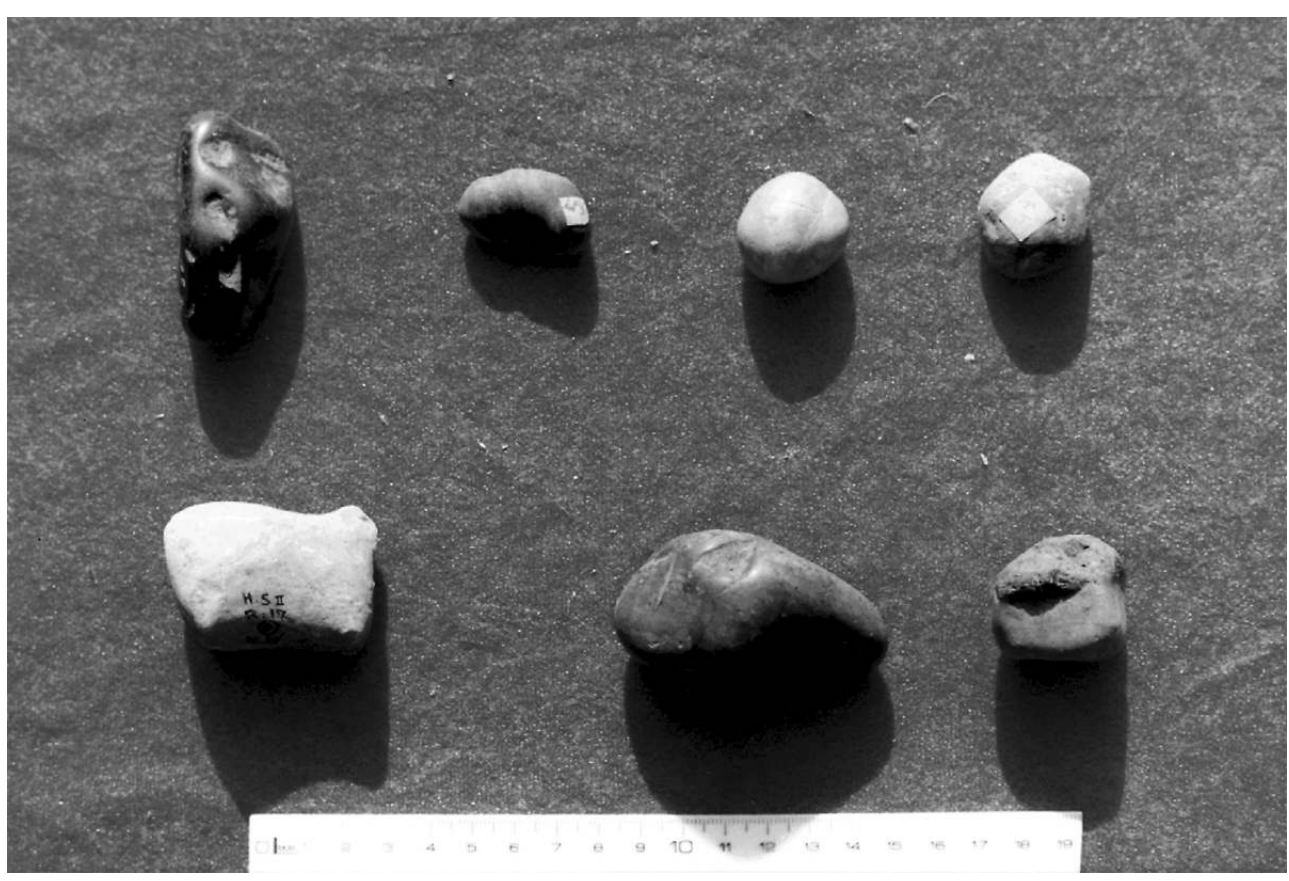


Fig. 10 - Los denominados "malleos" o conopas que se veneran hasta la actualidad en Huaros para propiciar la fertilidad del ganado

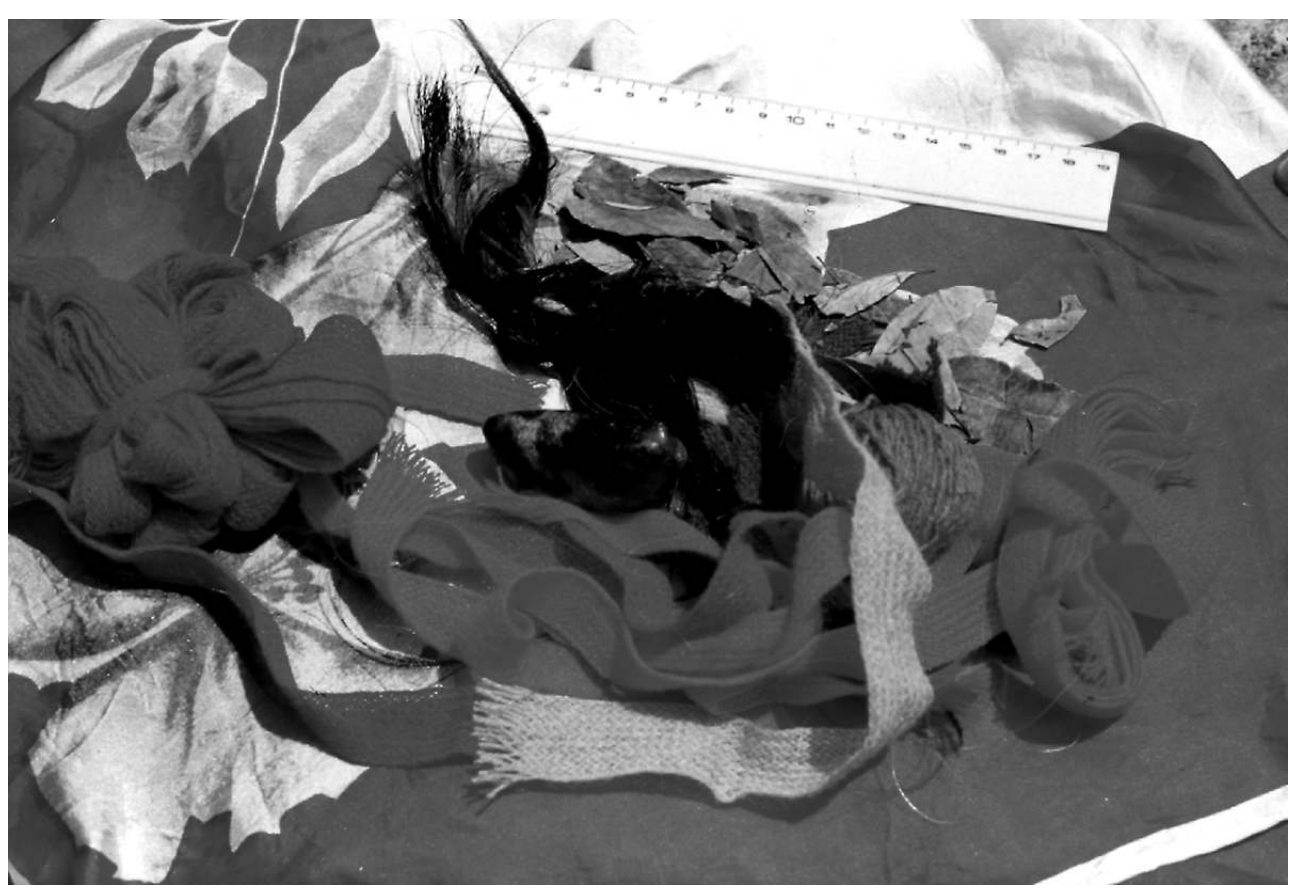

Fig. 11 - Los denominados "malleos" o conopas que se veneran hasta la actualidad en Huaros para propiciar la fertilidad del ganado

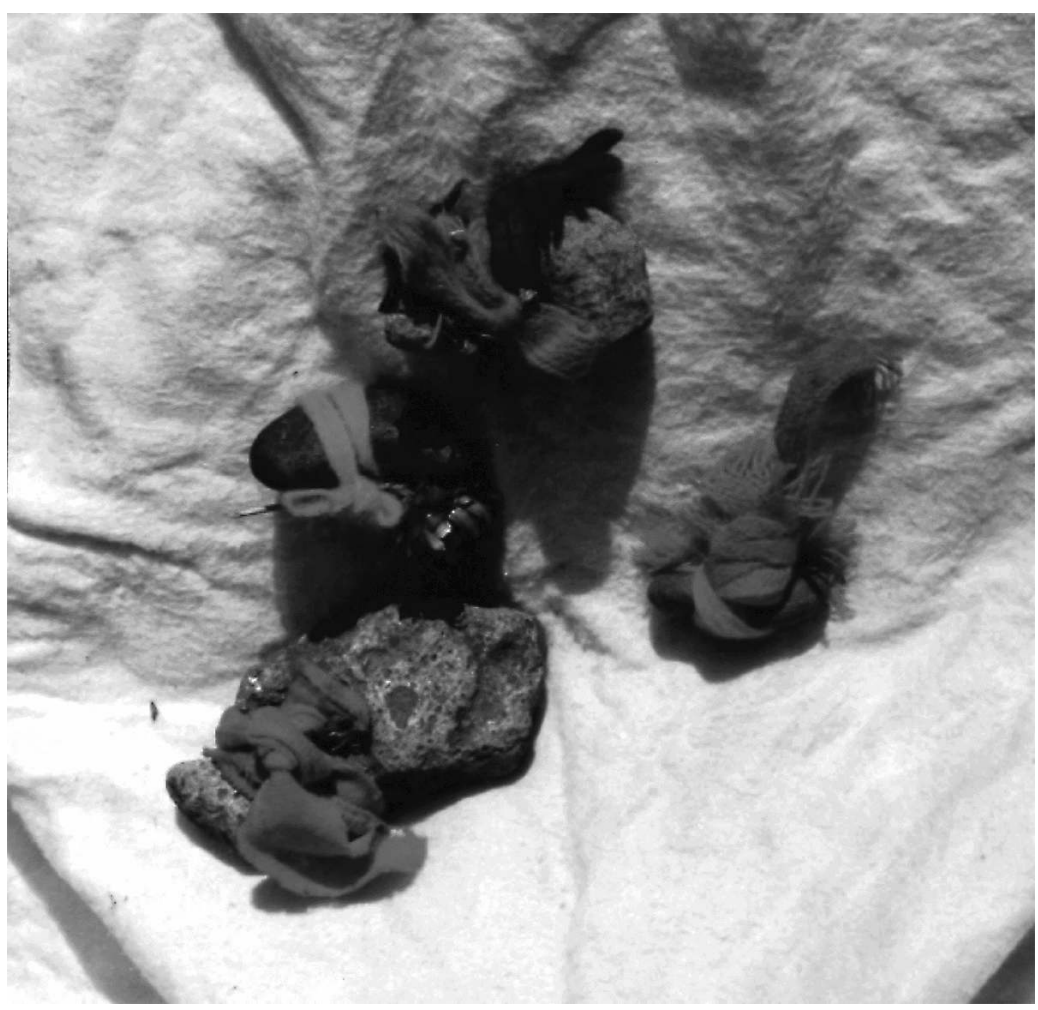

Esto nos hace pensar que todos estos elementos naturales y fenómenos meteorológicos forman parte del simbolismo en torno al agua (Fig. 12) y consecuentemente de la fertilidad que debía estar regulado por el tiempo circular, es decir, el ciclo agrario. 
Fig. 12 - Esquema del simbolismo del agua en Huaros

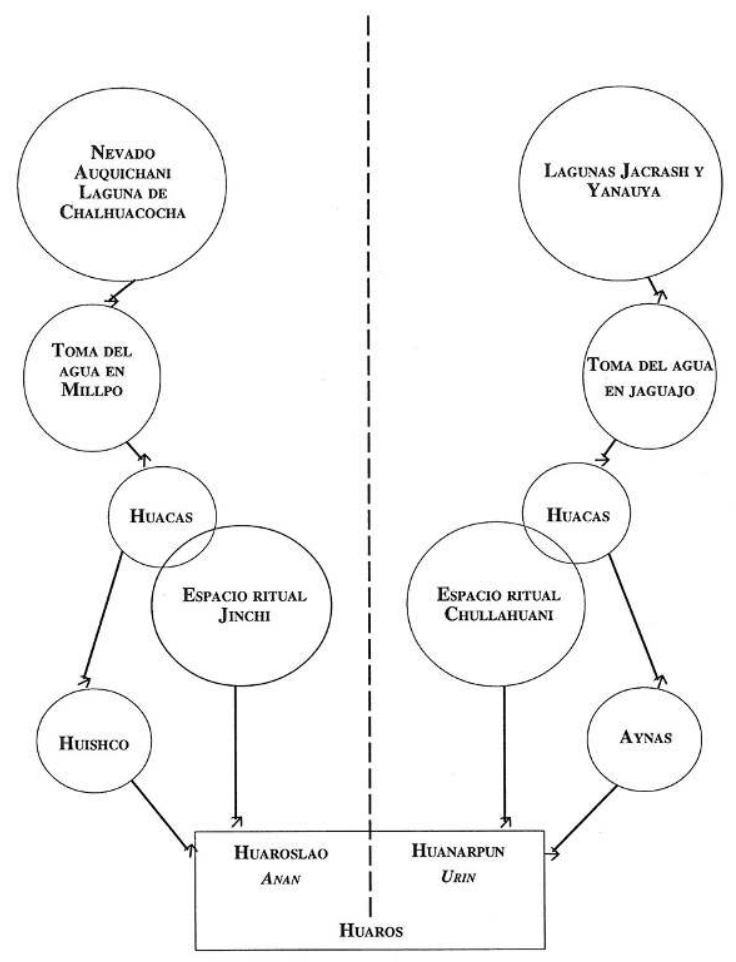

\section{El simbolismo en torno al agua}

La mayoría de los asentamientos prehispánicos de la cuenca del Chillón, al igual que Huishco y Aynas, están emplazados sobre promontorios muy elevados o cumbres de cerros. Por lo general, son asentamientos amurallados y ubicados estratégicamente que pueden tener uno o dos accesos a manera de portadas en falso arco. Para asentarse eligieron el lugar más propicio y adecuaron la pendiente, mediante la construcción de terrazas superpuestas (Farfán, 1995), pero manteniendo una orientación intencional del asentamiento en relación a su pacarina o lugar de origen que podría ser un cerro, una laguna o un puquio. En Lachaqui aún se mantiene un mito de origen en donde se explica que de la Laguna de Lorococha vinieron los primeros pobladores de Lachaqui; en Culluhuay se cuenta otro mito, donde señalan que los antiguos pobladores de Culluhuay bajaron de las alturas del cerro Naupajayan vestidos con cueros y en estado muy salvaje, y vivieron dentro de huecos hechos en los árboles. Joseph Arriaga, señala lo siguiente:

"Y esta es una de las causas, porque rehusan tanto la reducción de sus pueblos, y gustan de vivir en unos sitios tan malos, y trabaxosos, que algunos e visto que eran menester baxar por el agua cerca de una legua y a muchos no se puede baxar ni subir si no es a pie y la principal razón que dan es, que está allí su pacarina". (Arriaga, 1921: 21)

Como podemos ver hay aspectos recurrentes que se mantienen a través del tiempo, donde se indica con bastante claridad, que los asentamientos estaban ubicados, de algún modo, en relación a su huaca o pacarina. En este sentido (Fig. 3), Huishco se orienta hacia el nevado de Auquichani y la laguna de Chalhuacocha, y se encuentra al pie del cerro Jinchi en cuya cumbre se halla una cruz; mientras que Aynas está 
orientado hacia la laguna de Yanauya y esta al pie del cerro Chullahuani donde también hay una cruz. Ambas cruces son adoradas y enfloradas en cada limpia acequia a cargo de sus respectivos mayordomos y obviamente forman parte de la estructura ritual del culto al agua.

En consecuencia, podemos afirmar que estas orientaciones se refieren al flujo del agua que abastecía a los asentamientos de Huishco y Aynas en época prehispánica, incluyendo sus tierras de cultivo (Figs. 5, 4), y hoy abastece al pueblo de Huaros. La vertiente de Yamecoto (Canal de Mirpo), irriga las partes altas del poblado de Huaros y las de Acocancha (Canal de Jaguajo), las tierras bajas. Estos flujos son opuestos y discurren por las quebradas del mismo nombre: Yamecoto y Acocancha (Fig. 3). De cada una de estas vertientes se han captado los respectivos canales. El primero (Yamecoto) da origen al canal de Mirpo y, el segundo (Acocancha), al canal de Jaguajo.

La vertiente Yamecoto tiene su origen en las lagunas de Yapacocha y Chalhuacocha, que a su vez se forman de los deshielos del nevado Auquichani, mientras que Acocancha se origina en las cadenas de las lagunas de Jacrash, Yanauya y Turuman.

\section{Canal de Mirpo}

31 La ruta que sigue el canal de Mirpo se inicia en la toma denominado Pumapiupen, que quiere decir el rastro del puma. Luego de recorrer un tramo de $1200 \mathrm{~m}$, llega a un lugar denominado Mirpo donde existe una gran roca formando una cueva donde todos afirman que en su interior vive La Huaca personificada en una mujer (Fig. 13). Al respecto nuestro informante Don Alfonso Astudillo de 86 años nos dice:

"Mi abuelito Clemente Masgo me contó lo que vio cerca a la huaca (de Mirpo), era una mujer chiquita que recogía las flores que habían quedado después de la fiesta del agua."

Mientras que otro informante, el Señor José Masgo Astudillo de 78 años, nos contó:

"Se había presentado la huaca ahí en la cueva en momentos en que tenían problemas para hacer pasar el canal ya que era pura roca y necesitaban hacer la patacha que es la parte baja del muro, en estas circunstancias cuando pensaban por donde tendría que pasar el canal, se apareció de la cueva una mujer con su olla humeante, era la huaca, y les dijo: no se desanimen sigan su trabajo, de frente hagan su buena base de abajo hacia arriba y la acequia pasará de frente." 
Fig. 13 - La Huaca del canal de Mirpo donde se bautizan los recien llegados a la fiesta del agua

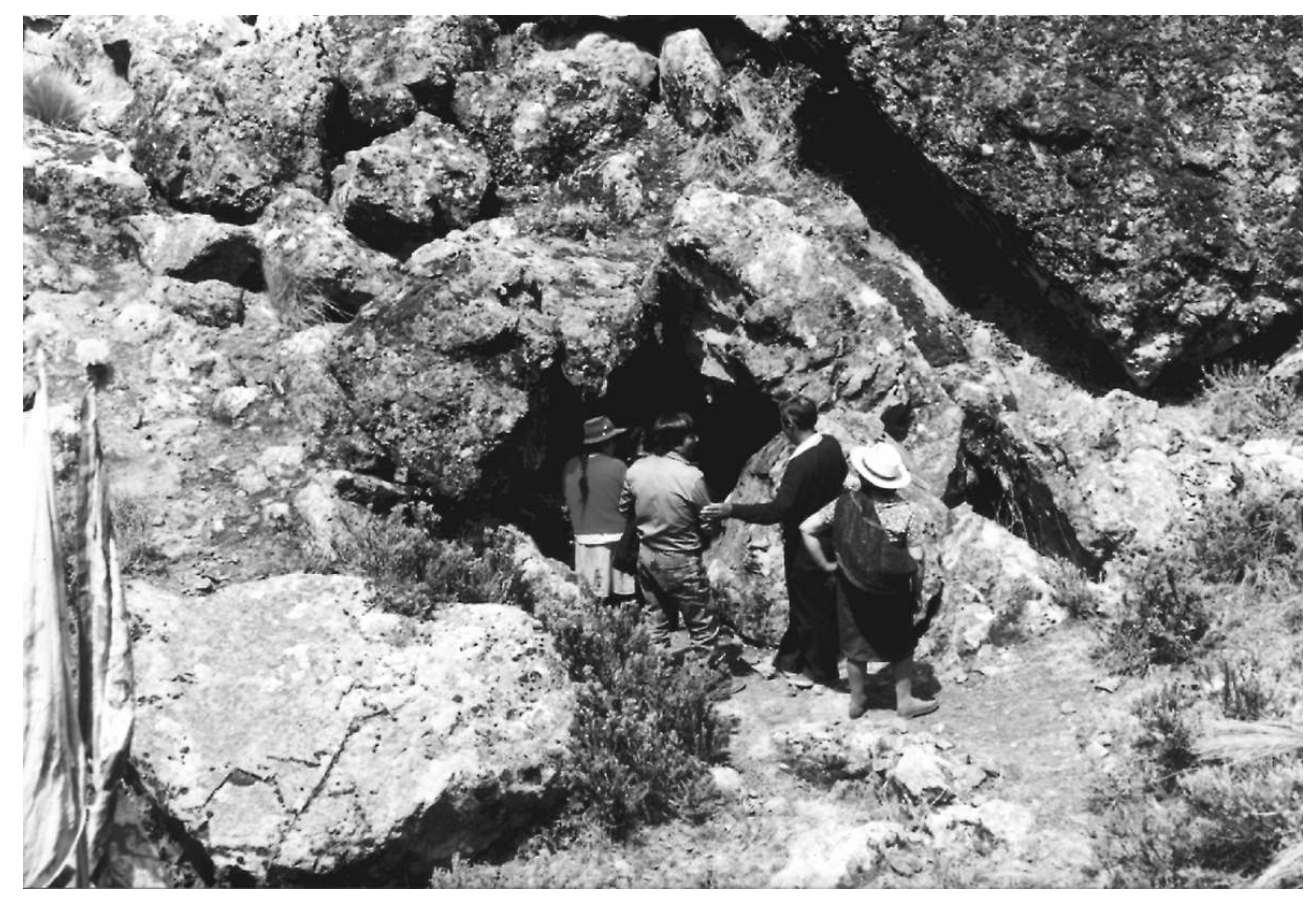

Esta huaca es muy temida y a la vez venerada. En cada limpia acequia el Inspector le hace comer sango ${ }^{6}$ negro (de maíz morado) muy de madrugada y es aquí donde las personas que vienen por primera vez se bautizan (Fig. 13) nombrando un padrino. Este bautizo se hace quemando un mechón del cabello con una rama de paja con la finalidad de ser protegidos por la huaca durante su estancia en $\mathrm{Mirpo}^{7}$. Delante de esta Huaca se prepara la mesa sagrada donde se sientan las autoridades del agua para rendir culto y cumplir con el ritual cada tercer domingo del mes de noviembre (Fig. 14). Al mismo tiempo, está presidido por la cruz Misionera de Jinchi que es venerada y enflorada y posteriormente llevada a la cumbre del cerro Jinchi. En el mismo trayecto, cerca a Huishco, se encuentra otro espacio de forma semicircular, que los huarosinos llaman Jayanpampa o Jayan, delimitado con muros de piedra y un vano de acceso orientado al Norte; al centro existen tres piedras largas de distintos tamaños fijadas sólidamente al suelo (Figs. 15, 16, 17). Aquí, hasta hace algunos años se bailaba conmemorando una de las paradas en la limpia acequia. El Jayan es mencionado repetidamente por Arriaga:

"Y no sólo reverenciaban las Huacas, pero aun los lugares donde dizen que descansaron, o estuvieron las Huacas, que llaman zamana, y a otros lugares de donde ellos las evocan, que llaman Cayan (ahora jayan), también los reverenciaban." (Arriaga, 1920: 23) 
Fig. 14 - La mesa sagrada donde se realiza el ritual tanto a la huaca como a las cruces en la limpia acequia de Mirpo. En la parte superior, el canal a manera de acueducto de construcción prehispánica

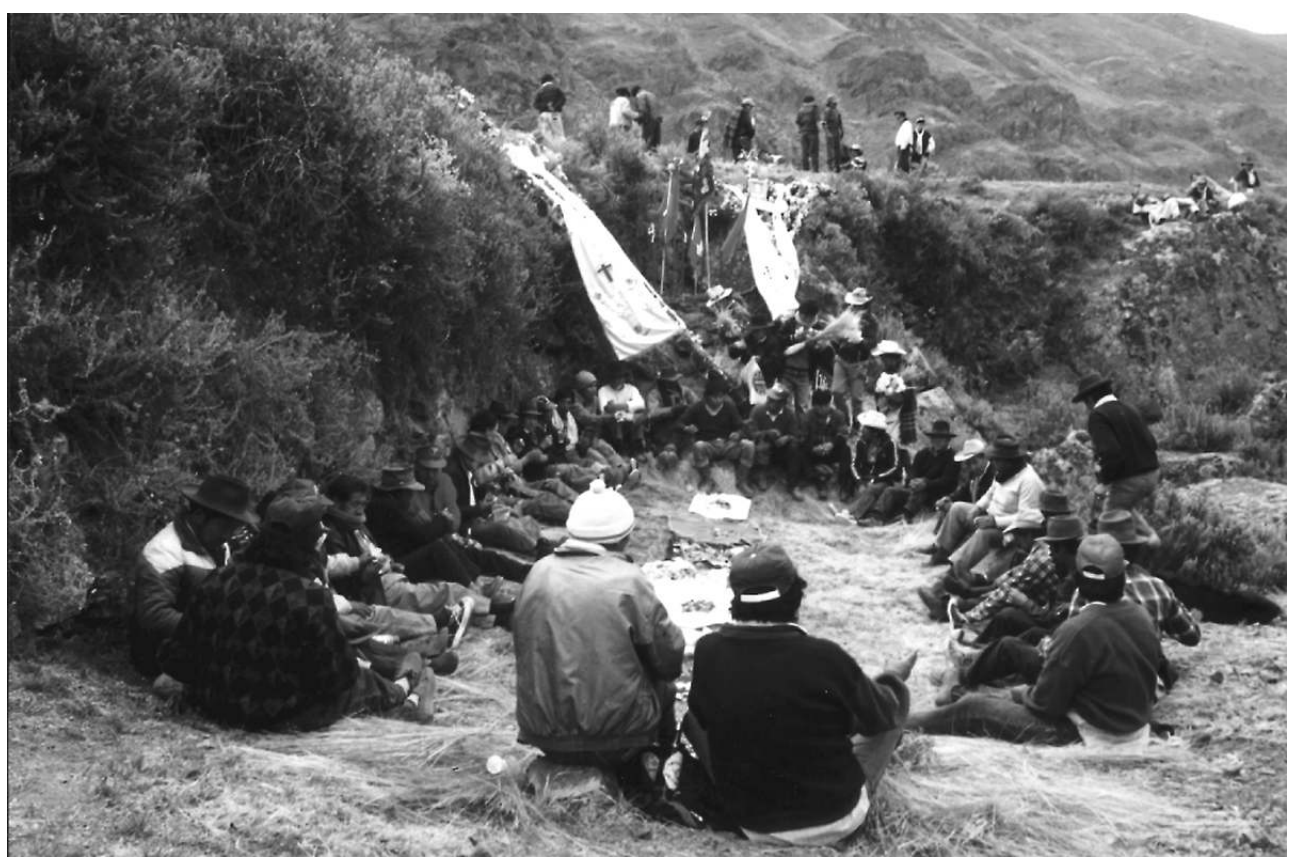

Fig. 15: El Jayampampa de Huishco con las tres huancas y la roca mayor partida por el rayo (al fondo a la derecha)

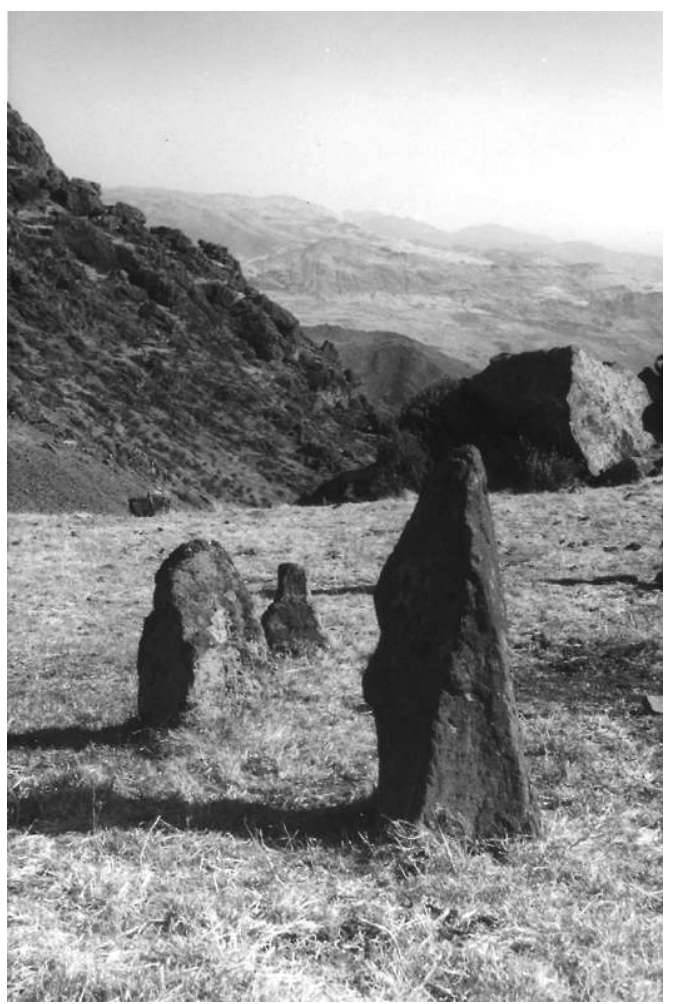




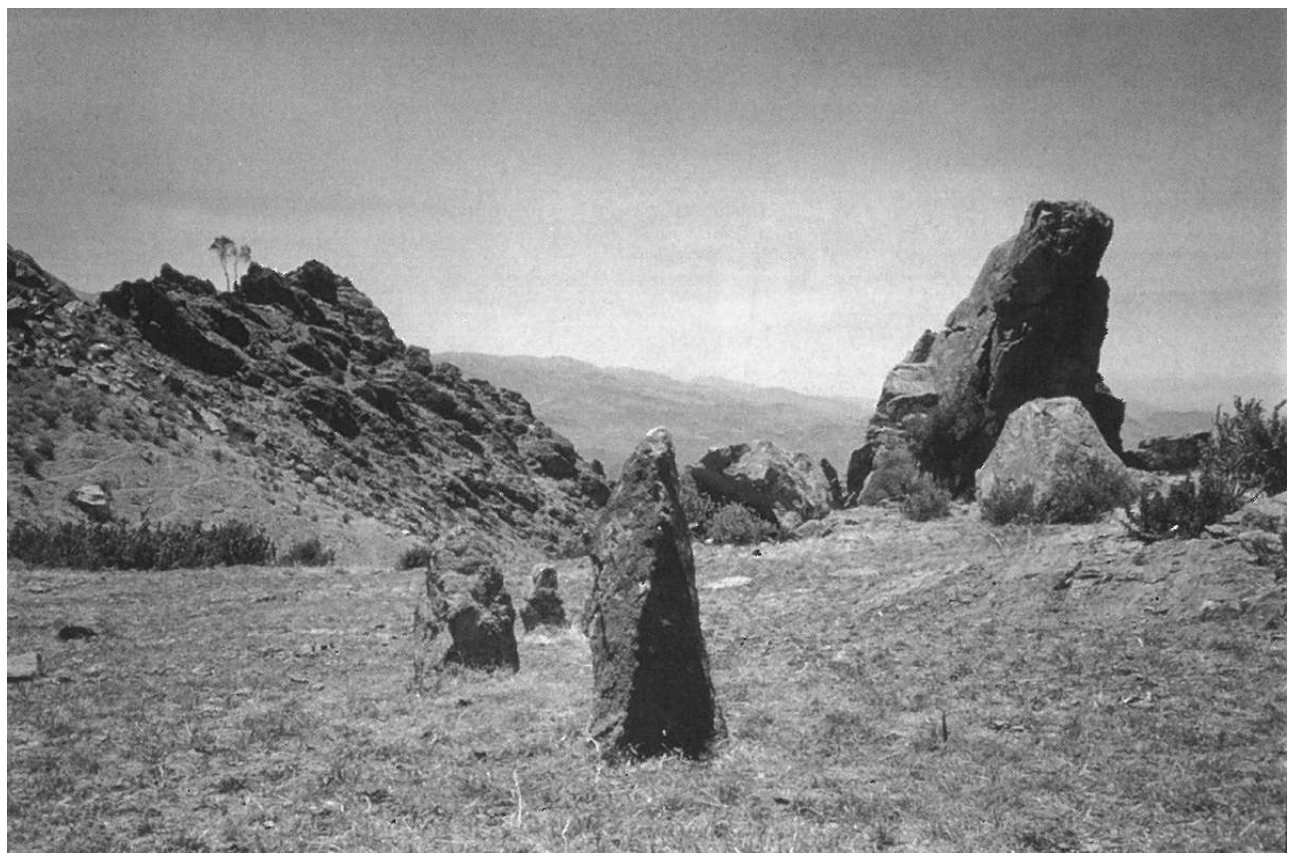

Fig. 17 - Huishco, plano de Jayanpampa

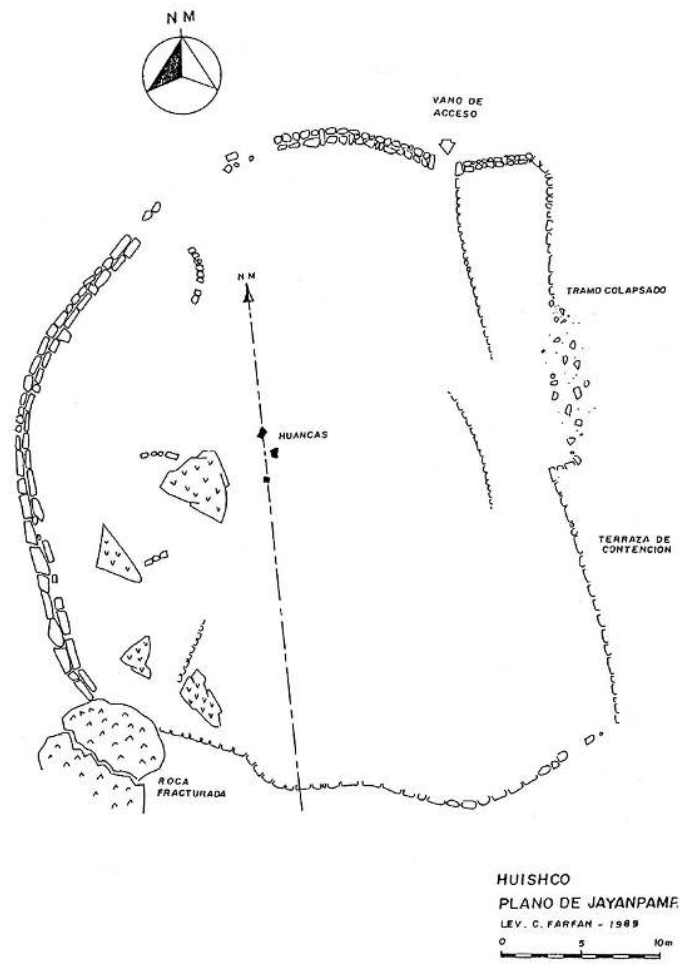

Otro dato similar es el que aparece en la visita de Bernardo de Novoa a San Pedro de Acas donde Ynes vpiai declara que :

“... para selebrar las fiestas de sus guacas y en vnas plasetas que tienen las puertas de las colcas que llaman cayanes las dichas colcas son de los ydolos en las dichas plasetas bia haser las seremonias y ritos" (Duviols, 1986). 
Ambas versiones señalan que la denominación Cayan o Jayan se refiere a una plaza sagrada destinada a ritos dedicados a las huacas. No sabemos si estas piedras eran huancas y simbolizaban a deidades relacionadas con el agua o como dice Duviols "La Huanca como toda huaca de piedra, es aposento de los espíritus de los muertos y de los dioses" (Duviols, 1986: 164). En este sentido, la denominación de Jayan aún se mantiene en Huaros cuando se refieren a las plazas Jayanpampa y Ñaupajayan, lo que nos demuestra que los nombres de estas plazas se mantienen desde la época prehispánica cumpliendo en algunos casos las mismas funciones. Luego de esta plaza el canal continúa hacia Marcapacche, una catarata que llega directamente a otro espacio denominado Muyuncucha (laguna circular) donde se realiza una ceremonia el primer día de la limpia acequia. De este lugar sigue para llegar a Huaycache, el último lugar sagrado donde se efectúa la Asamblea Comunal frente a las 7 banderas el primer día de la limpia acequia. Finalmente el canal se dirige hacia el pueblo hasta desembocar en el río en el paraje denominado Asuspucro.

\section{Canal de Jaguajo}

La vertiente Acocancha nace de las lagunas de Jacrash y Yanauya y sigue la ruta de Jaspacancha, Acocancha, hasta llegar a Jaguajo lugar de la toma del Canal de Jaguajo que también lleva el nombre de Runtu (Fig. 3). Cerca a esta toma se encuentra una pareja de huacas materializadas en piedra: la primera, llamada "La Vieja", se halla en medio del río. Se trata de una piedra grande amorfa que a veces sólo el comunero puede identificar (Fig. 18). La otra, se encuentra sobre el canal cerca de la toma y se llama " $\mathrm{El}$ Viejo"; es una piedra alargada de 1,50 m. de alto, ligeramente tallada, muy lisa, que fue colocada intencionalmente al borde del canal (Figs. 8, 19). Referente a estas huacas hay dos relatos recogidos en Huaros por nosotros. El primero contado por Don José Masgo Astudillo, dice:

"Un tal Paredes que pasaba por ahí (Jaguajo), venía de su estancia a la población y vio que el río (Acocancha) se encontraba desviado por media falda por donde esta "La Vieja" (la Huaca), entonces él ya no pudo pasar. Pero surgió una idea para la comunidad, hacer el canal y traer esa agua para su comunidad, pero nunca se termino este canal y posteriormente construyeron el canal actual por más abajo." 
Fig. 18 - La huaca denominada "la vieja" que radica en la paccha

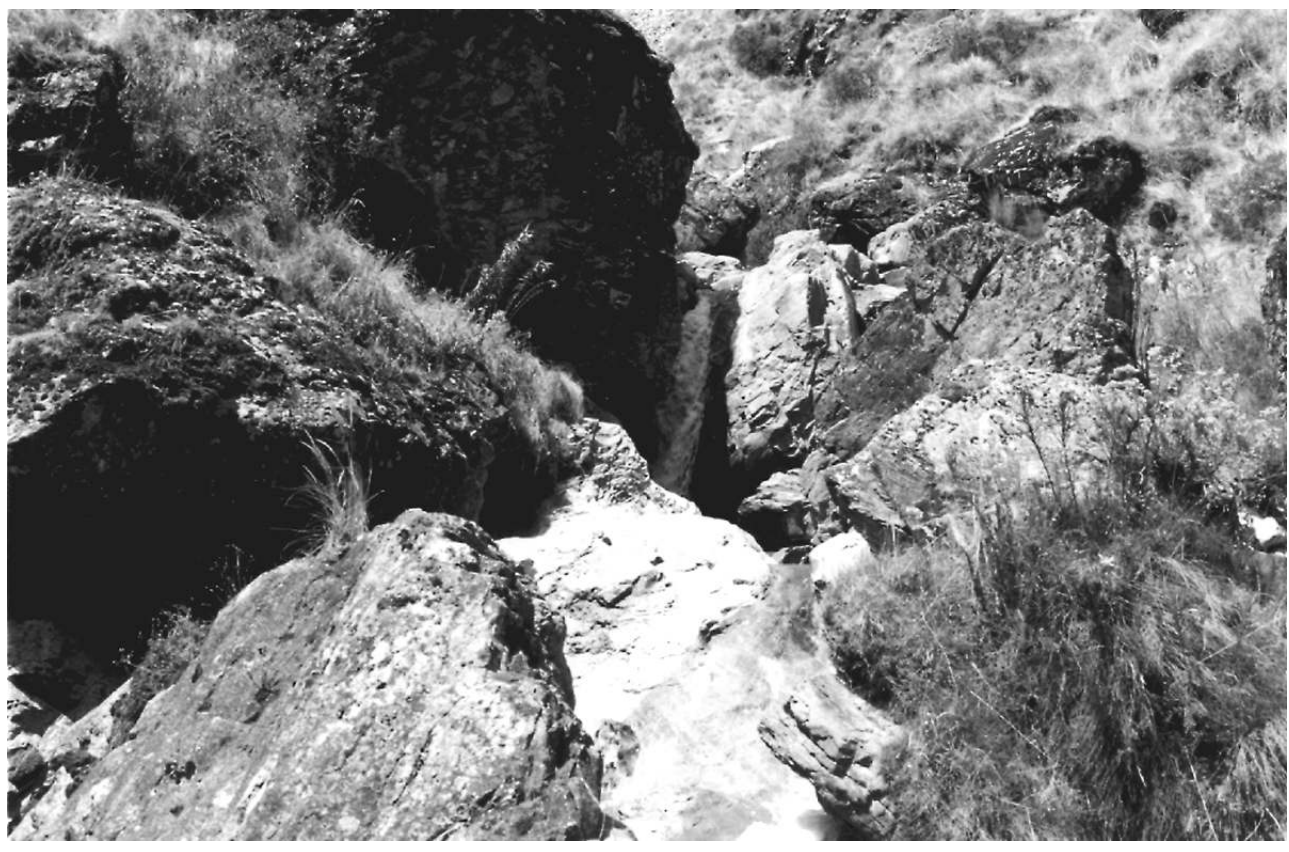

Fig. 19 - "El Viejo" o huanca de piedra que se halla en Jaguajo cerca de la toma del canal y la cruz de Chullahuani

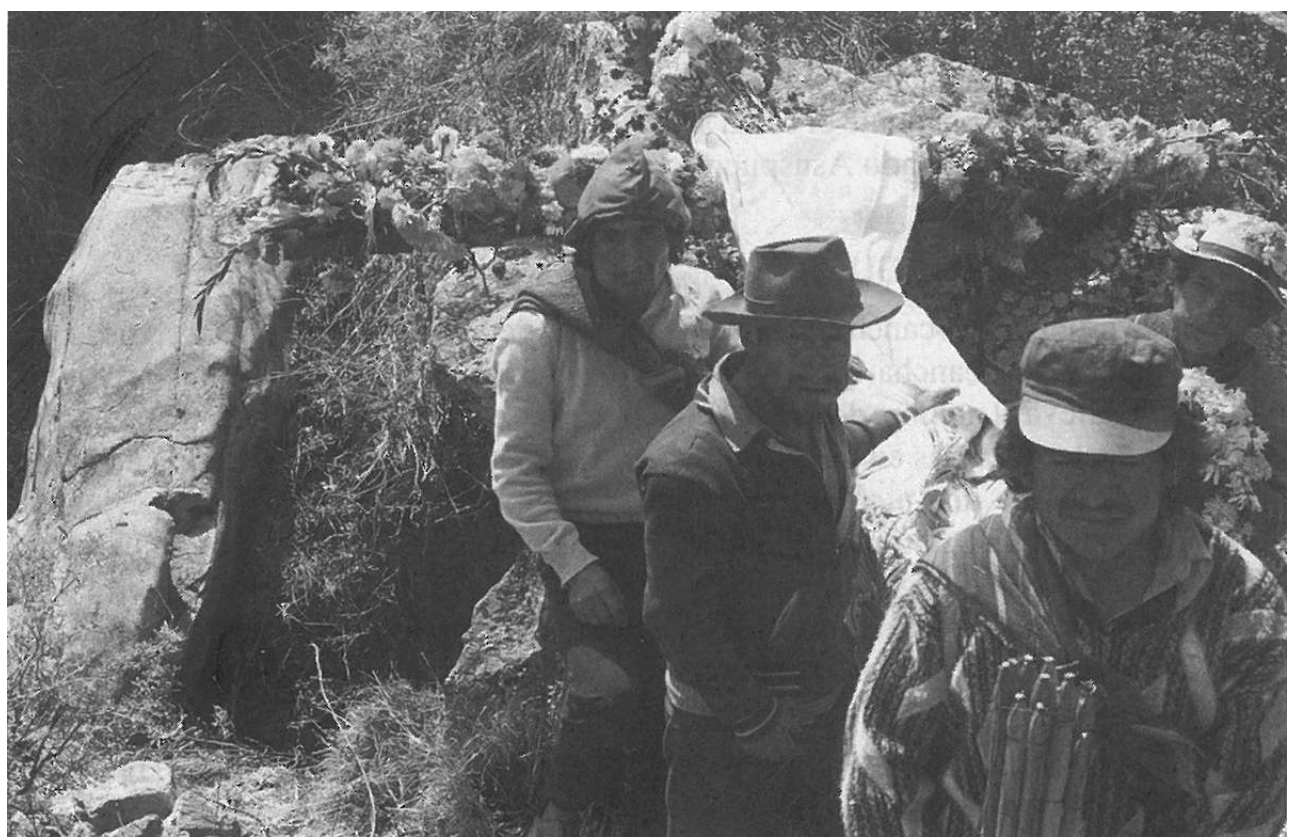

El segundo es contado por Don Benigno Hacha Mosquito, y dice:

“Allá por arriba había unos criaderos de ganado lanar, entonces cuando iba por ahí, en el lugar de Jaguajo, había los dos cerros ahí, no le dejaba pasar, y qué era, que habían dos piedras grandes y esos se habían convertido mas antes en una vieja y un viejo así es que cuando la gente iba después no le dejaba pasar, tenían que ponerle su coca y su cigarro."

Como se puede ver en ambos relatos hay un común denominador: el personaje es un pastor de las alturas (llacuaces?) que se pierde en el camino y no puede pasar por culpa de las huacas y en el otro caso, por culpa de los dos cerros. Sin embargo siempre son 
dos elementos. En cuanto a la litificación de los héroes fundadores relacionados con el agua y más específicamente con los canales, encontramos en Ritos y Tradiciones de Huarochiri:

"Cuando llegaron, la mujer llamada Chuquisuso le dijo: aquí en mi acequia [en la bocatoma del canal] me voy a quedar y se transformó en piedra. La mujer llamada Chuquisuso aun se encuentra petrificada en la bocatoma de esta acequia de Cocochalla." (Taylor, 1987: 135). ceremonia en estos lugares donde se puede identificar una deidad del agua materializada en piedra.

41 Hay otra explicación para el canal de Jaguajo, también llamado Runtu lo que significa huevo. Algunos informantes mencionan que este canal es de la fertilidad, de las sementeras. En la trayectoria del canal existe un espacio donde se venera una cruz denominada "la cruz de los solteros" y otra llamada "la cruz de los cazados", formando una dualidad de oposición y complementariedad. La mayordomía de la cruz de los casados es asumida por los comuneros, mientras que una pareja de solteros asume la de la curz de los solteros, lo que explicaría un poco más el carácter de propiciación de la fertilidad puesto que los solteros son los que pronto procrearán y deben realizar estos ritos para ser fertilizados por las huacas. Al mismo tiempo se puede identificar tres períodos en la estructura ritual de estas huacas, el primero, la época de los ancestros personificados por las huacas y los constructores del canal, el segundo conformado por las autoridades comunales que controlan el agua durante el año y simbolizan el presente y el tercero los solteros o jóvenes, comuneros potenciales tanto en la fertilidad como en la formación de las familias futuras, que explicaría la continuidad y permanencia.

Como en el caso de la vertiente Yamecoto, en Acocancha existe un espacio ritual denominado Jaguajo donde se rinde homenaje a las huacas que se consideran dueñas del agua; se venera asimismo una cruz (además de las cruces de solteros y casados), enflorada y luego llevada a la cumbre del cerro Chullahuani (Fig. 19). Tanto las dos huacas, como la cruz de Chullahuani están relacionadas con el asentamiento viejo de Aynas. las tierras bajas de Huaros, que pertenecían a Aynas en época prehispánica.

Ambos flujos del agua, tanto la vertiente Yamecoto como la de Acocancha tienen relación con la fundación de Huishco y Aynas en el Período Intermedio Tardío (siglos XI y XII) y mantienen hasta la actualidad sus antiguos orígenes, incluso resistiendo las reducciones toledanas del siglo XVI. De manera que de estos datos se puede inferir que tanto Aynas como Huishco mantenían una relación cultural de oposición, puesto que sus pacarinas y huacas residían en distintos lugares Sin embargo, tenían concordancia para controlar los recursos. Los de Huishco se relacionan con el cerro Auquichani asociado a la laguna Chalhuacocha, con su huaca en Mirpo, mientras que para los de Aynas su pacarina era las lagunas de Jacrash y Yanauya relacionadas con su gran cerro Chullahuani. Concluyentemente podemos decir que tanto los huishcos como los aynas fundaron sus pueblos en la misma época (siglo XII) pero tuvieron orígenes étnicos 
distintos, por lo que sus territorios estaban delimitados. En consecuencia, la fundación de su asentamiento se orientó hacia la dirección de donde vinieron cada grupo. Sin embargo la similitud estructural de la circulación del agua entre ambos grupos nos sugiere dos posibilidades:

1) puede corresponder a una organización dual mucho más antigua que fue retomada en el espacio Huaros en una etapa migratoria;

2) tomando en cuanta los trabajos de Duviols (Duviols, 1973), podemos ver que hay un grupo originario Huari que podría ser los Huishco, y otro Llacuaz advenedizo que vendría a ser los Aynas.

De este modo, el actual pueblo de Huaros está dividido en dos barrios Huaroslao (anan) y Huanarpun (urin) donde se juntan la dualidad simbólica en torno al agua (Fig. 12).

\section{Comentarios Finales}

La articulación del presente con el pasado en la comunidad de Huaros puede depender de varios factores, sin embargo, cuando recurrimos a su cosmovisión encontramos una estrecha relación de los comuneros con sus ancestros a través de una variada gama de rituales propiciatorios y de los espacios sagrados donde radican sus huacas. Huaros nos proporciona un conjunto de relatos en torno a la circulación del agua basados en una serie de mitos y creencias compartidos con varias comunidades de la región andina. En este caso, durante las faenas hidráulicas festivas hay un control racional y a la vez simbólico del agua por parte de las autoridades tradicionales, el cual está relacionado con tribunales públicos, divisiones sociales especiales (las paradas)y una antigua forma gerontocrática de gobierno (Gelles, 1986: 120). La vigencia de los ritos y más aún de las huacas materializadas en piedra a manera de Huancas en Huaros, es una clara evidencia que el sistema hidraúlico y el ciclo agrario funcionan dentro de un esquema racional y ancestral.

Dentro de esta realidad la situación actual de la producción agrícola en Huaros no es del todo satisfactorio. Hay varios factores que han generado desmoralización en el comunero, como las sequías cíclicas, la migración, y el desentendimiento por parte de los organismos gubernamentales. Estos factores han contribuido paulatinamente al olvido de sus tecnologías tradicionales limitando la producción que por lo general no llega a satisfacer el autoconsumo. Huaros controla varios pisos ecológicos donde se puede contar con un $50 \%$ de terrenos de secano y un 50\% de riego. La presencia de dos canales ancestrales indica que el problema del agua siempre fue presente, pero su mantenimiento en la actualidad no se hace de la misma manera que hace 100 años atrás. Cuentan los ancianos huarosinos que para la limpieza de canales se utilizaban una arcilla especial denominada "chupaca" que era traída como parte de los rituales en la limpia acequia. Este barro era utilizado para impermeabilizar los puntos de filtración. Esto garantizaba que el $100 \%$ del agua captada llegaba en los regadíos, lo que no sucede en la actualidad donde un $40 \%$ del agua aproximadamente se pierde por filtración. De este modo, la limpia acequia en Huaros esta perdiendo su esencia funcional aunque su esencia simbólica y de unidad aún persiste. En Huaros la fiesta del agua conduce al comunero a un clímax de instauración y renovación de nuevas promesas, de críticas y autocríticas. Mediante las asambleas a campo abierto junto a la huaca y junto a la cruz, las danzas, las melodías que se tocan y cantan en esta ocasión, así como la narración de 
los mitos, unen el presente con el pasado, al anciano con el joven y de este modo transcurre el tiempo en la comunidad de Huaros.

\section{BIBLIOGRAFÍA}

ARRIAGA, J. de, 1920 [1621] - Extirpación de la Idolatría del Perú. In: Colección de libros y documentos referentes a la historia del Perú, Tomo 1 (Segunda Serie), 215p.; Lima.

CONSTANZA, M., 1999 - Cumbres Sagradas del Noroeste Argentino: Avances en Arqueología de Alta Montaña y Etnoarqueología de Santuarios de Altura Andino; 105p.; Buenos Aires: Ed. Universitaria.

DUVIOLS, P., 1967 - Un inédito de Cristobal de Albornoz: "La Instrucción para descubrir todas las guacas del Piru y sus camayos y haziendas". Journal de la Société des Américanistes, LVI-1: 7-39; Paris.

DUVIOLS, P., 1973 - Huari y Llacuaz. Agricultores y pastores. Un dualismo prehispánico de oposición y complementariedad. Revista del Museo Nacional, Tomo XXXIX: 153-191; Lima.

DUVIOLS, P., 1986 - Cultura Andina y Represión: Procesos y visitas de idolatrías, Cajatambo, siglo XVII, 570p; Cusco: Centro de Estudios Rurales Andinos Bartolomé de las Casas.

FARFÁN LOBATON, C., 1993 - La Bipartición del Espacio y el Sistema de Plazas en los asentamientos prehispánicos de la cuenca del Chillón. In: Canta y su Historia: Posibilidades de Desarrollo (B. Ramírez \& W. Icochea eds.): 27-32; Lima.

FARFÁN LOBATON, C.,1995 - Asentamientos Prehispánicos de la Cuenca alta del Chillón. Gaceta Arqueológica Andina, Vol. VII No 24: 31-61; Lima: INDEA.

GELLES, P., 1986 - Sociedades Hidraúlicas en los Andes: Algunas Perspectivas desde Huarochirí. Allpanchis, N 27, año XVIII: 99-147; Cusco: Instituto de Pastoral Andina.

LLANOS, O., 1986 - Ritual de la Fiesta del Agua en San Pedro de Casta, Perú, 40p.; Lima: Impresiones nuebo waris. "Champería”, Asociación Costeña Residentes en Lima, Chosica, Callao y Balnearios.

MARISCOTTI DE GORLITZ, A. M., 1972 - La posición del Señor de los fenómenos meteorológicos en los panteones regional de los andes centrales. Historia y Cultura, $\mathbf{N}^{\mathbf{0}}$ 6,: 207-215; Lima: INC.

MARTÍNEZ, G., 1976 - El Sistema de los Uywiris en Isluga. In: Homenaje al Dr. Gustavo Le Paige: 255-327; Antofagasta.

MARTÍNEZ, G., 1983 - Los Dioses de los cerros en los Andes. Journal de la Société des Américanistes, Tomo 69: 85-115; Paris.

MATOS MENDIETA, R., 1994 - Pumpu: Centro Administrativo Inka de la Puna de Junín, 327p; Lima: Editorial Horizonte, B.C.R., Fondo Editorial.

REINHARD, J., 1983 - Las Montañas Sagradas: Un Estudio Etnoarqueológico de Ruinas en las Altas Cumbres Andinas. Cuadernos de Historia, Vol. 3: 27-62; Santiago.

REINHARD, J., 1987 - Las Líneas de Nasca: un nuevo enfoque sobre su origen y significado, 78p.; Lima: Editorial Los Pinos. 
SHERBONDY, J., 1982 - El regadío, los lagos y los mitos de origen. Allpanchis, vol. XVII, Nº 20: 3-32; Cusco.

POLO DE ONDEGARDO, J., 1917 [1571] - Relación de los Fundamentos acerca del notable daño que resulta de no guardar a los indios sus fueros. In: Colección Libros y Documentos referentes a la Historia del Perú, Serie 1, Tomo 3, 45-188; Lima

TAYLOR, G., 1987 - Ritos y Tradiciones de Huarochirí. Manuscrito quechua de comienzos del siglo XVII, 618p. Lima: Instituto de Estudios Peruanos - Instituto Francés de Estudios Andinos.

TELLO, J. C. \& MIRANDA, P., 1923 - Wallallo: Ceremonias Gentilicias realizadas en la Región Cisandina del Perú Central. Revista Inca, Vol. I: 474-549; Lima.

VALDERRAMA, R. \& ESCALANTE, C., 1988 - Del Tata Mallky a la Mamapacha. Riego, Sociedad y Ritos en los Andes Peruanos, 243; Lima: DESCO Centro de Estudios y Promoción del Desarrollo.

VILLAR CÓRDOBA, P., 1933 - El mito del “Wa-Kon y los Willka” referente al culto indígena de la cordillera La Viuda. Revista del Museo Nacional, Tomo II, N²: 162-179; Lima.

\section{NOTAS}

1. Hondear: voz española que significa tomar una honda (huaraca) y lanzar piedras. En el mundo andino aún se usan las huaracas hechas de tejido de lana de llama o vicuña.

2. Culluhuay es el último poblado de la cuenca del Chillón. Se halla sobre los 3600 m.s.n.m., corresponde a la región Suni, pero su posición geográfica lo hace más propenso a recibir los vientos helados del este procedentes del nevado de La Viuda. Ocupa una explanada sobre la ribera derecha del río Chillón. No hay vegetación abundante, su entorno está conformado por las laderas de los cerros que forman la quebrada. Tiene una población de 450 habitantes que se dedican a la ganadería. Sus sitios arqueológicos son Cushpa y Ñaupajayan.

3. Huaca de Chuchun: en un relato recogido en Culluhuay se menciona que durante la incursión de los Bombón hacia Canta hubo una resistencia en la fortaleza de Capur de Culluhuay y el jefe bombón raptó a tres princesas de Culluhuay. Estas cautivas huyeron de sus captores en tres direcciones: una se fue a las alturas de Ñaupajayan donde se convirtió en piedra, otra en su huida se quedó en medio del río y también se convirtió en piedra, que hasta hoy se puede ver cerca al pueblo de Culluhuay; la otra princesa huyó hacia la cordillera de la Viuda y se perdió en la laguna de Chuchun donde hasta ahora figura la piedra en el centro de la laguna.

4. Lachaqui: se ubica en la quebrada alta de Arahuay sobre su margen izquierda a los 3650 m.s.n.m. Tiene una población que sobrepasa los 700 habitantes quienes se dedican a la ganadería. Mantienen con mucho vigor sus tradiciones ancestrales, destacando la "champería", la "herranza", la festividad de "María Pallacha" diosa de las lluvias. Conserva importantes sitios arqueológicos o ñaupallactas, como Cullpe, Cushumarca, Cochacalla y Aymará.

5. Los cronistas informan que las acequias tenían sus huacas personificadas en piedras que eran guardianes o dueñas del agua. Arriaga menciona: “Compa, o Larca, villana llaman otras piedras a este mismo modo que tienen en las acequias, a las quales hazen la misma reverencia antes sembrar, y después de pasadas las aguas, porque las acequias no se les quiebren, y les falte el agua.

6. Sango o Sanku, es una masa preparada a base de maíz, con sangre de llama, sin sal y es comida de los dioses. En Lachaqui cuando se envía a la búsqueda del agua a los puquios más alejados, los comuneros llevan de fiambre el sango, al igual que en Huaros a la Huaca de Mirpo.

7. Es muy común estos bautizos en las limpia acequias del valle alto del Chillón. En Huacos, un poblado más bajo que Huaros, sobre la misma margen, hacen el bautizo en una paccha (catarata 
de agua) donde nace el canal (toma) y se le llama Ongongoy. Aquí se bautiza a las mujeres con una flor mojando la cabeza en la paccha, a los varones con una piedra de la paccha y frotando la cabeza en círculos. En San José de Tauripuncu, más abajo, sobre la misma margen, el bautizo se hace en una paccha donde nace el canal, tanto hombre como varón tienen que cruzar la paccha y regresar sin mojarse; luego son bañados con chicha y derraman el resto al canal. En todos los casos cada persona nombra a su respectivo padrino.

\section{RESÚMENES}

En el transcurso de las investigaciones arqueológicas y etnográficas llevadas a cabo en el alto valle del Chillón, hemos recopilado numerosas informaciones que nos permiten explicar la continuidad cultural basada en la creencias y tradiciones orales vigentes en la actualidad, pero que sin duda van a desaparecer bajo la presión de la modernidad y la tecnología. Intentaremos acá definir algunos elementos simbólicos asociados con creencias magico-religiosas en relación con el agua, que explican los ritos de fertilidad que tienen que ver con el origen del pueblo de Huaros.

Este pueblo se formó a partir de los antiguos poblados de Huishco y Aynas. Estos dos establecimientos coexistieron durante el Intermedio Tardío (siglos $\mathrm{XI}^{\mathrm{e}}$ y XII ${ }^{\mathrm{e}}$ d.C.) y funcionaban como dos entidades complementarias en cuanto a la gestión de su economía.

Esta complementariedad generó una organizacion dual que perduró hasta la llegada de los españoles y más allá, generando dos barrios: Huaroslao para los que eran de Huishco y Huanarpun para los que eran de Aynas.

$\mathrm{Au}$ cours des recherches archéologiques et ethnographiques menées dans la vallée haute du Chillón, nous avons récolté de nombreuses informations permettant d'expliquer la continuité culturelle basée sur les croyances et les traditions orales qui perdurent actuellement, mais sont inexorablement condamnées à disparaître sous la pression de la modernité et de la technologie. Nous tenterons ici d'expliquer quelques éléments symboliques associés aux croyances magicoreligieuses en relation avec l'eau, lesquels éclairent les rites de fertilité complexes en rapport avec l'origine du village de Huaros.

Le village de Huaros s'est formé à partir des établissements anciens de Huishco et Aynas. Ces deux établissements ont coexisté durant l'intermédiaire récent (XI ${ }^{\mathrm{e}}$ et $\mathrm{XII}^{\mathrm{e}} \mathrm{s}$.) et fonctionnaient comme deux entités complémentaires au niveau de la gestion de leur économie. Cette complémentarité a généré une organisation duale qui a perduré jusqu'à l'arrivée des Espagnols et au-delà, formant dans la réduction nouvellement créée, deux quartiers : Huaroslao pour ceux issus de Huishco et Huanarpun pour ceux provenant de Aynas.

During the archaeological and ethnographic investigations in the upper valley of the Chillon River, we have collected abundant information that explain the oral tradition-based cultural continuity that remains until now, but is condemned to disappear because of the pressure of technology and modernity. We explain some symbolical elements related to water-associated magical and religious beliefs. This symbolism helps to explain the complex rituals of fertility related to the origins of the Huaros community.

The current village of Huaros derives from two ancient settlements: Huishco and Aynas. Both coexisted during the Late Intermediate Period (AD 1100-1300) and functioned as two 
complementary entities at the level of economic management. That complementarity generated a dual organization that survived the Spanish conquest and beyond, forming two quarters in the newly created colonial settlement of Huaros. Huaroslao for those coming from Huishco and Huanarpun for those coming from Aynas.

\section{ÍNDICE}

Keywords: Cantas, Huaros, oral tradition, symbolism, water-cult, bipartition of space

Palabras claves: Canta, Huaros, tradición oral, simbolismo, culto al agua, bipartición del espacio Mots-clés: Cantas, Huaros, tradition orale, symbolisme, culte de l'eau, bipartition de l'espace

\section{AUTOR}

\section{CARLOS FARFÁN LOBATON}

Universidad Nacional Federico Villareal, Facultad de Humanidades, Escuela Profesional de Arqueologia y Antropología, Av. Nicolas de Piérola 351, Lima. E-mail: carlosf21@yahoo.com 